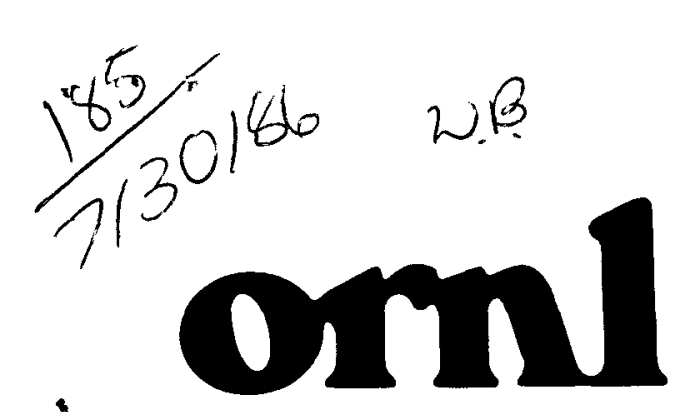

\section{OAK RIDGE NATIONAL LABORATORY}

MARTIN MARUETRA

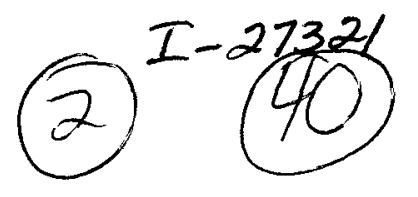

$D E-1852 x$

ORNL-6270

\title{
A Consumable Arc-Melting, Extruding, and Rolling Process for Iridium Sheet
}

R. L. Heestand

G. L. Copeland

M. M. Martin

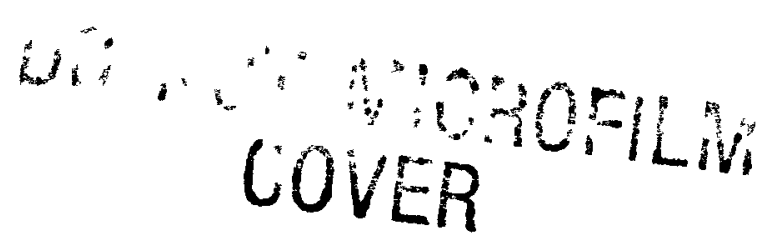

OPERATED QY

MARTIN MARIETTA ENERGY SYSTEMS, NC.

FOR THE UNTED STATES

DEPARTMENT OF ENERGY 


\section{DISCLAIMER}

This report was prepared as an account of work sponsored by an agency of the United States Government. Neither the United States Government nor any agency Thereof, nor any of their employees, makes any warranty, express or implied, or assumes any legal liability or responsibility for the accuracy, completeness, or usefulness of any information, apparatus, product, or process disclosed, or represents that its use would not infringe privately owned rights. Reference herein to any specific commercial product, process, or service by trade name, trademark, manufacturer, or otherwise does not necessarily constitute or imply its endorsement, recommendation, or favoring by the United States Government or any agency thereof. The views and opinions of authors expressed herein do not necessarily state or reflect those of the United States Government or any agency thereof. 


\section{DISCLAIMER}

Portions of this document may be illegible in electronic image products. Images are produced from the best available original document. 


\section{Printed in the United States of America. Available from National Technical Information Service \\ U.S. Department of Commerce \\ 5285 Port Royal Road, Springfield, Virginia 22161 NTIS price codes-Printed Copy: A03 Microfiche A01}

This report was prepared as an account of work sponsored by an agency of the United States Government. Neither the United States Government nor any agency thereof, nor any of their employees, makes any warranty, express or implied, or assumes any legal liability or responsibility for the accuracy, completeness, or usefulness of any information, apparatus, product, or process disclosed, or represents that its use would not infringe privately owned rights. Reference herein to any specific commercial product, process, or service by trade name, trademark, manufacturer, or otherwise, does not necessarily constitute or imply its endorsement, recommendation, or favoring by the United States Government or any agency thereof. The views and opinions of authors expressed herein do not necessarily state or reflect those of the United States Government or any agency thereof. 
ORNL -6270

Dist. Category UC-25

METALS AND CERAMICS DIVISION

A CONSUMABLE ARC-MELTING, EXTRUDING, AND ROLLING PROCESS FOR IRIDIUM SHEET

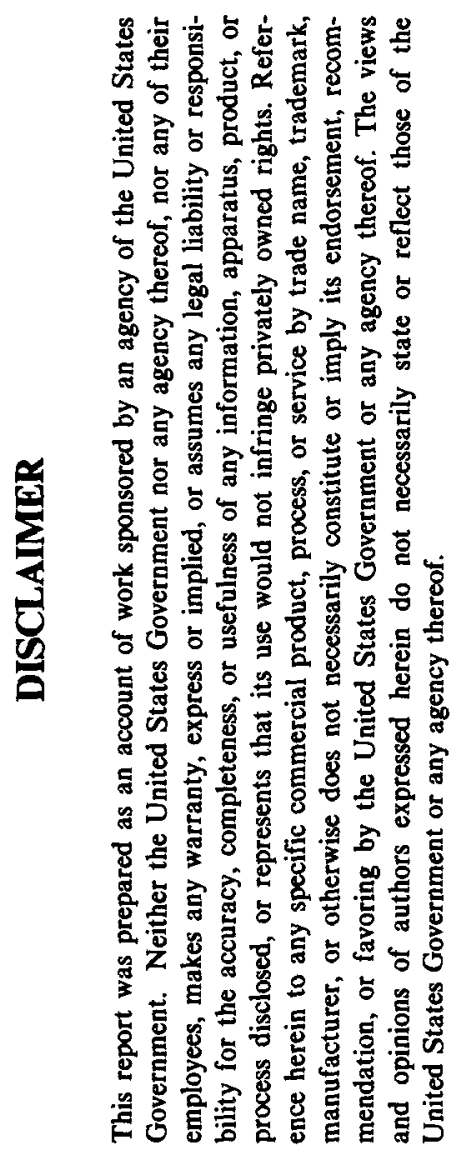

R. L. Heestand

G. L. Copeland

M. M. Martin

ORNL --6270

DE86 013524

Date Published: June 1986

Prepared for

DOE Division of Special Applications

Prepared by the

OAK RIDGE NATIONAL LABORATORY

Oak Ridge, Tennessee 37831

operated by

MARTIN MARIET'TA ENERGY SYSTEMS, INC.

for the

U.S. DEPARTMENT OF ENERGY

under Contract No. DE-AC05-840R2 1400 
CONTENTS

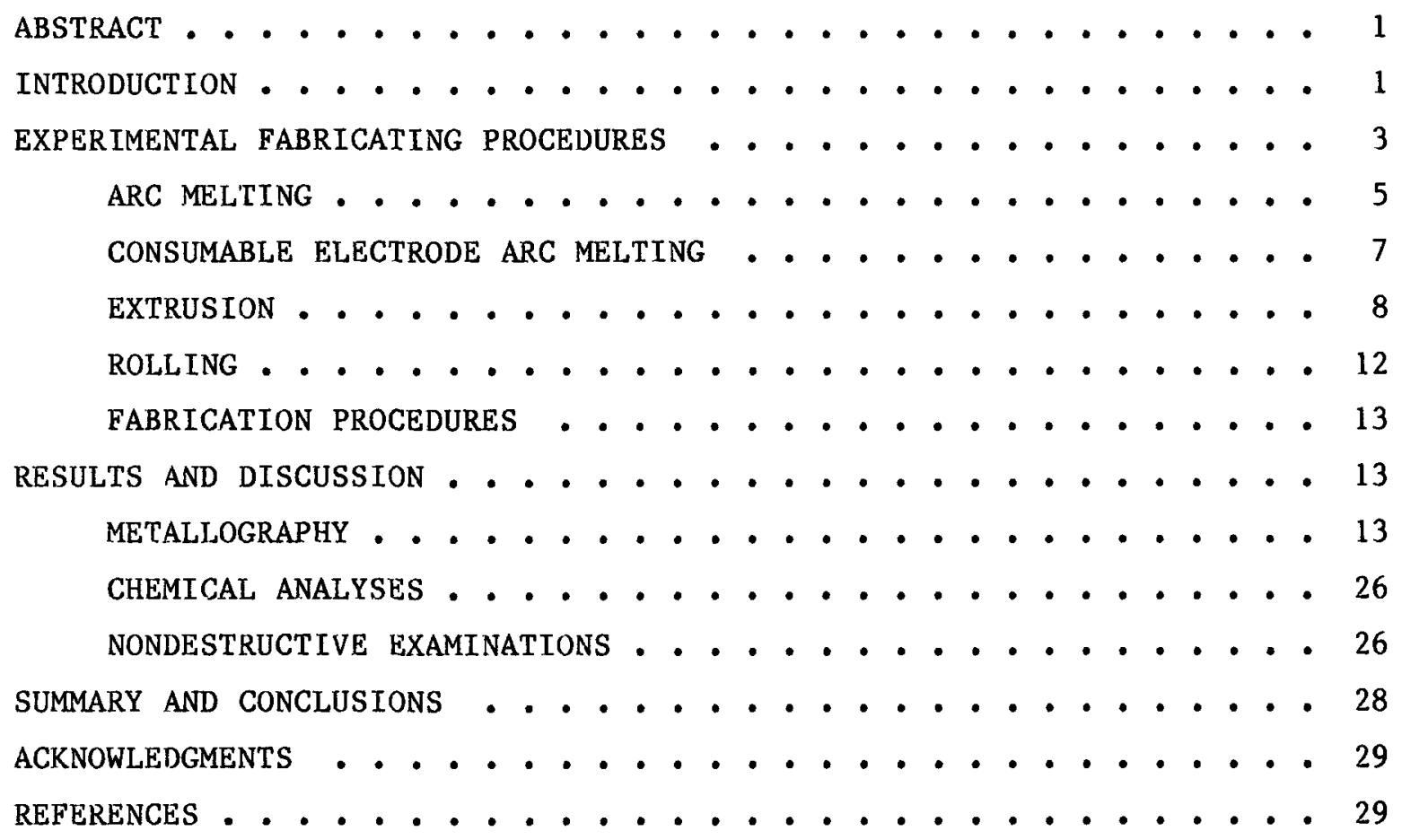


A CONSUMABLE ARC-MELTING, EXTRUDING, AND ROLLING PROCESS FOR IRIDIUM SHEET*

R. L. Heestand, G. L. Copeland, and M. M. Martin

\title{
ABSTRACT
}

\begin{abstract}
An iridium alloy has been used as cladding for the ${ }^{238} \mathrm{PuO}_{2}$ fuel in radiolsotope thermoelectric generators (RTGs) for recent interplanetary spacecraft such as Voyagers 1 and 2 and will be used for the Galileo and Ulysses spacecraft. The iridium alloy sheet for the fuel cladding used on these missions was fabricated by hot and cold rolling of arc-melted and drop-cast $0.5-\mathrm{kg}$ ingots. Upon completion of production for these spacecraft, an opportunity was taken to conduct process improvement studies that would increase processing batch sizes, develop a more uniform product, decrease rejections due to internal delaminations and surface defects, and reduce costs. The studies to scale up and improve the fabrication process are described herein. In the new process, iridium is electron beam melted, alloyed by arc melting, and then consumable arc melted to form a cylindrical ingot of approximately $7 \mathrm{~kg}$ for extrusion. The ingot is extruded to sheet bar and hot and cold rolled into sheet. Sheet evaluated from the first two ingots showed $100 \%$ acceptance with no defects on inspection. An improved uniformity of microstructure was obtained, and chemistry was controlled within specification limits.
\end{abstract}

\section{INTRODUCTION}

For several years, Oak Ridge National Laboratory (ORNL) has supplied Monsanto Research Corporation, Mound Plant (MP), with flight-quality iridium alloy hardware for use in isotope heat sources. ${ }^{1}$ A sheet fabricating procedure originally developed in the 1970 s for an $\operatorname{Ir}-0.2$ to $0.4 \mathrm{wt} \% \mathrm{~W}$ alloy 2,3 was used for Voyagers 1 and 2 spacecraft. Recently, the fabrication procedure was also used for a DOP-26 alloy 4,5 of Ir-0.2 to $0.4 \mathrm{wt} \% \mathrm{Wt}$ 30 to $90 \mathrm{ppm}$ Th-20 to $80 \mathrm{ppm}$ Al for the Galileo and Ulysses spacecraft.

${ }^{*}$ Research sponsored by the Division of Special Applications, Office of Defense Energy Projects and Special Applications, office of Nuclear Energy, U.S. Department of Energy, under contract DE-AC05-840R21400 with Martin Marietta Energy Systems, Inc. 
In 1984, a study was initiated to improve the old fabrication procedure in order to obtain a more uniform grain structure for the recrystallized sheet and to reduce the quantity of rejected material owing to internal delaminations and surface defects. Our approach addressed two major changes in the fabrication procedure. The first was to modify the rolling schedule on standard arc-melted and drop-cast $0.5-\mathrm{kg}$ ingots to determine the optimum amount of rolling reduction required on the casting to ensure a uniformly worked structure before recrystallization. It was also necessary to select a recrystallizing temperature after the initial reduction that would give uniform grain size before rolling the plate to final thickness. The control of worked structure and recrystallization would give equiaxed grains when the worked plate was annealed. The second change in the fabricating procedure was to make a large 7-kg ingot by the consumable-electrode arc-melting process to determine whether ingot porosity could be eliminated and to demonstrate the feasibility of casting a billet of sufficient size to extrude into rectangular bar and then roll into sheet.

A rolling experiment in 1984 demonstrated that increased hot reduction prior to recrystallization and lowering of the recrystallizing temperature from 1400 to $1300^{\circ} \mathrm{C}$ produced a uniform structure for final working. The microstructure of the final rolled sheet, after a recrystallization heat treatment of $1 \mathrm{~h}$ at $1500^{\circ} \mathrm{C}$, revealed nearly equiaxed grains. Equiaxed grains after annealing at $1500^{\circ} \mathrm{C}$ are important, as formed iridium cups are recrystallized at that temperature.

In another experiment, two standard-sized rolling sections cut from a consumable arc-melted ingot were found to be free of large porosity and shrinkage cavities as determined by radiographic examination. Measurements of weight and volume by displacement techniques gave calculated values for both sections that approached theoretical density that indicated fine porosity was not present. The sections were rolled by the standard process, and the resultant sheets were fabricated into forming blanks of about $52-\mathrm{mm}$ in diameter by $0.65-\mathrm{mm}$ thick. No indication of delamination was found by ultrasonic inspection, and only one blank was rejected for a defect detected by dye penetrant. 
The successful results of the previous two preliminary processimprovement experiments in fiscal year 1984 led to further support under the 1985 Radioisotope Thermoelectric Generator (RTG) Materials Production and Technology Task at ORNL from the Division of Special Applications, Office of Defense Energy Projects and Special Applications, Office of Nuclear Energy, U.S. Department of Energy. Our objective of the continued study was to determine if the quality of DOP-26 alloy blanks can be improved significantly by casting an ingot by consumable-electrode arc melting, extruding the ingot to rectangular bar, and then producing sheet from the bar with a rolling schedule modified for the extruded geometry. The goal was to reduce the ultrasonic-defect-indication rejection rate of finished blanks from approximately $30 \%$ to $15 \%$ or below during production. The material must fulfill the MP specification SPA790430 for blanks. Production qualification of the consumable arc-extrusion route iridium blank process will include demonstration of (1) fabricability in cup forming at MP, (2) weldability of the clad cup configuration at the Savannah River Plant (SRP) of E. I. du Pont de Nemours \& Company, and (3) determination of high-strain-rate biaxial mechanical properties at the Los Alamos National Laboratory (LANL).

\section{EXPERIMENTAL FABRICATING PROCEDURES}

The fabricating process for conversion of iridium powder to a finished DOP-26 alloy blank is a relatively complicated task consisting of several operations. In developing the procedures for process improvement, many of the standard operations remained the same as those used to produce blanks for the general purpose heat source ${ }^{l}$ for the Galileo and Ulysses spacecraft. Procedures for powder preparation, electron beam melting, machining, and final cleaning, sampling, and inspecting were identical to the standard procedures. The length of the standard-sized ingot was increased to produce long sections for the consumable arc-melting electrodes; however, the major changes were to add processes for consumable arc-melting, extruding, and modifying the rolling procedure. The development of each procedure is discussed in the following sections, along with the results of evaluating the produced material. A schematic diagram of the process modifications is shown in Fig. 1. 
ORNL-DWG 86-8312

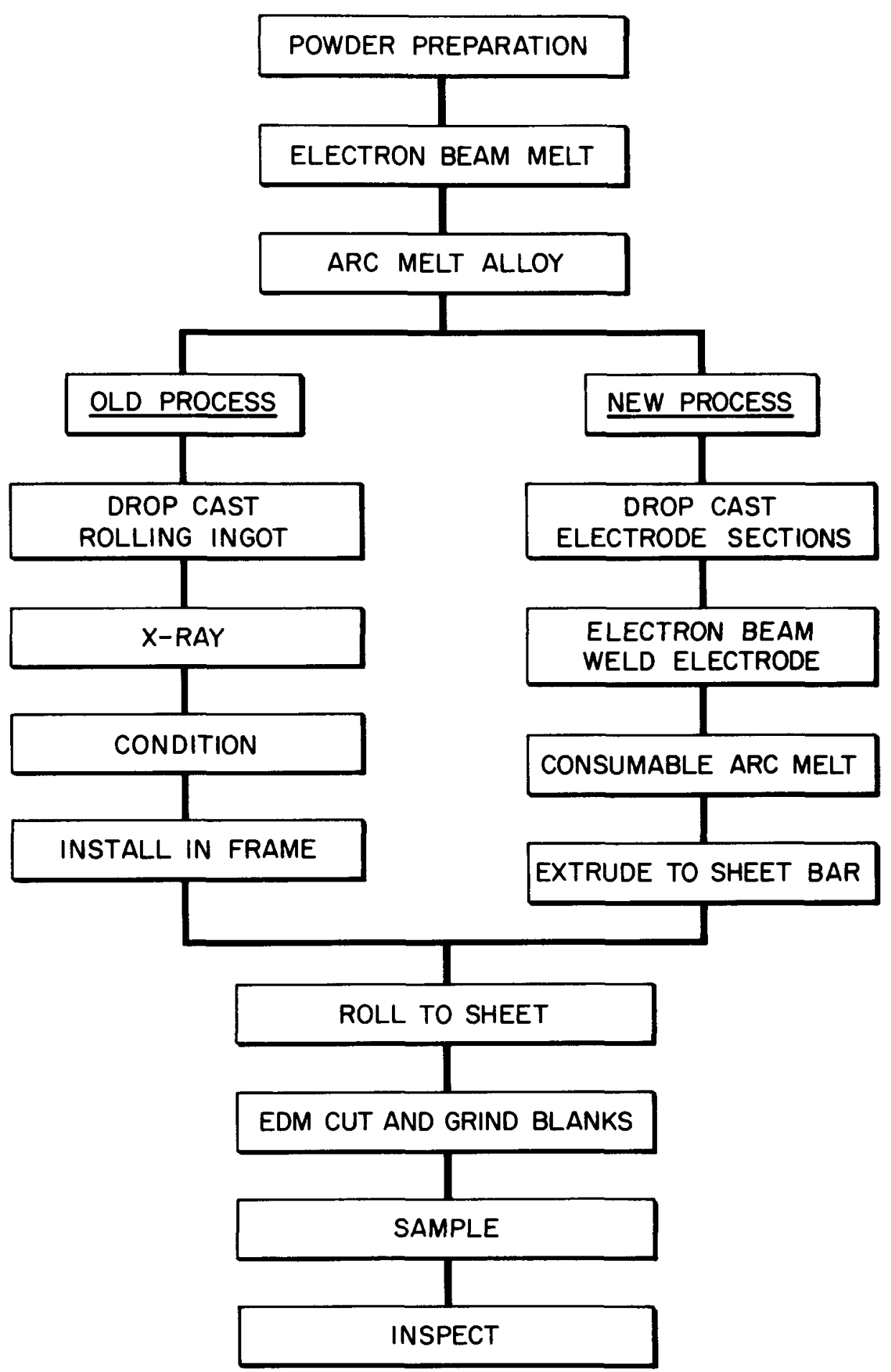

Fig. 1. Schematic diagram of process modification for production of DOP-26 alloy blanks. 
ARC MELTING

The old arc melting and alloying procedure entails remelting electron-beam-melted iridium buttons containing 0.2 to 0.4 wt \% W and adding master alloys containing approximately 2 wt $\%$ of aluminum and thorium to give the DOP-26 composition ( $\mathrm{Ir}-0.2$ to $0.4 \mathrm{wt} \% \mathrm{~W}-30$ to $90 \mathrm{ppm}$ Th-20 to $80 \mathrm{ppm} \mathrm{Al).} \mathrm{The} \mathrm{alloyed} \mathrm{button} \mathrm{is} \mathrm{arc} \mathrm{melted} \mathrm{six} \mathrm{times} \mathrm{for} \mathrm{homo-}$ geneity and then drop cast. In the standard procedure, the arc-melted material is drop cast into a rectangular ingot $19 \times 19 \times 54 \mathrm{~mm}(3 / 4 \times 3 / 4$ $\times 21 / 8 \mathrm{in.)}$. The ingot weighs approximately $500 \mathrm{~g}$ after removal of the head (approximately $250 \mathrm{~g}$ ) and sku11 (approximately $400 \mathrm{~g}$ ) portions, which are recycled. Figure 2 shows the ingot after the head has been removed by sawing. The centrally located shrinkage cavity has been sealed by electron beam welding.

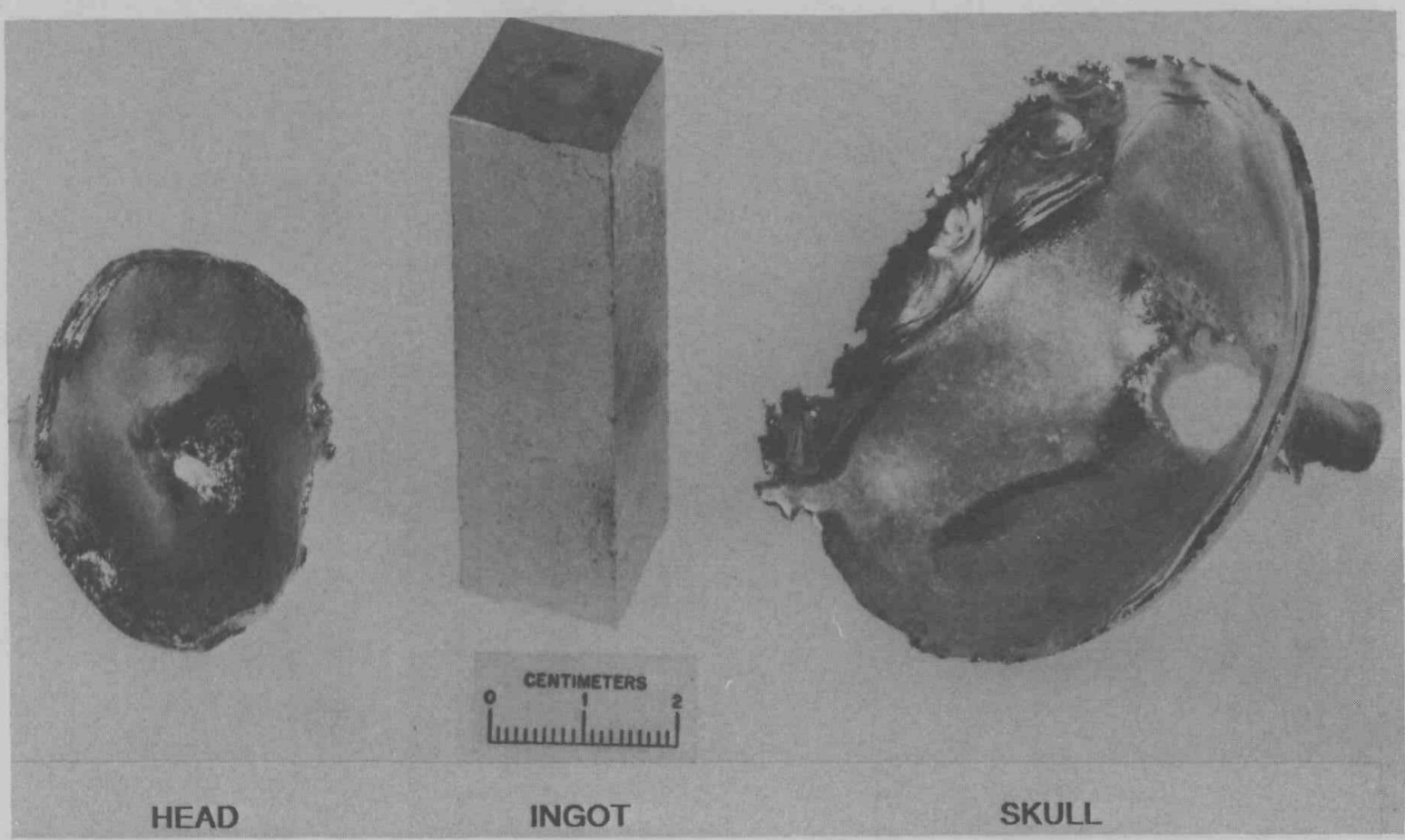

Fig. 2. Appearance of standard arc-cast and welded ingot, cut head, and skull. 
In the new process, the button is alloyed by the standard arc melting procedure. The arc-melted button is then drop cast into a water-cooled copper mold of $28.6 \mathrm{~mm}$ in diameter by $139.7 \mathrm{~mm}$ deep ( 1.125 by $5.50 \mathrm{in.}$ ) to produce electrode castings. Since the resultant cylindrical ingot is to be used as an electrode, three buttons can be cast sequentially in the same mold before removal. The as-cast ingots had clean surfaces, and the consecutive drop castings bonded well to each other. Since the skulls from the drop casting crucible are recycled each time, only one skull is left as recycle material after the preparation of all the electrode castings. Figure 3 shows four multiple cast electrode sections, a reusable DOP-26 alloy electrode threaded adapter, and a reusable cast DOP-26 alloy striking pad to protect the bottom of the consumable arc melting crucible.

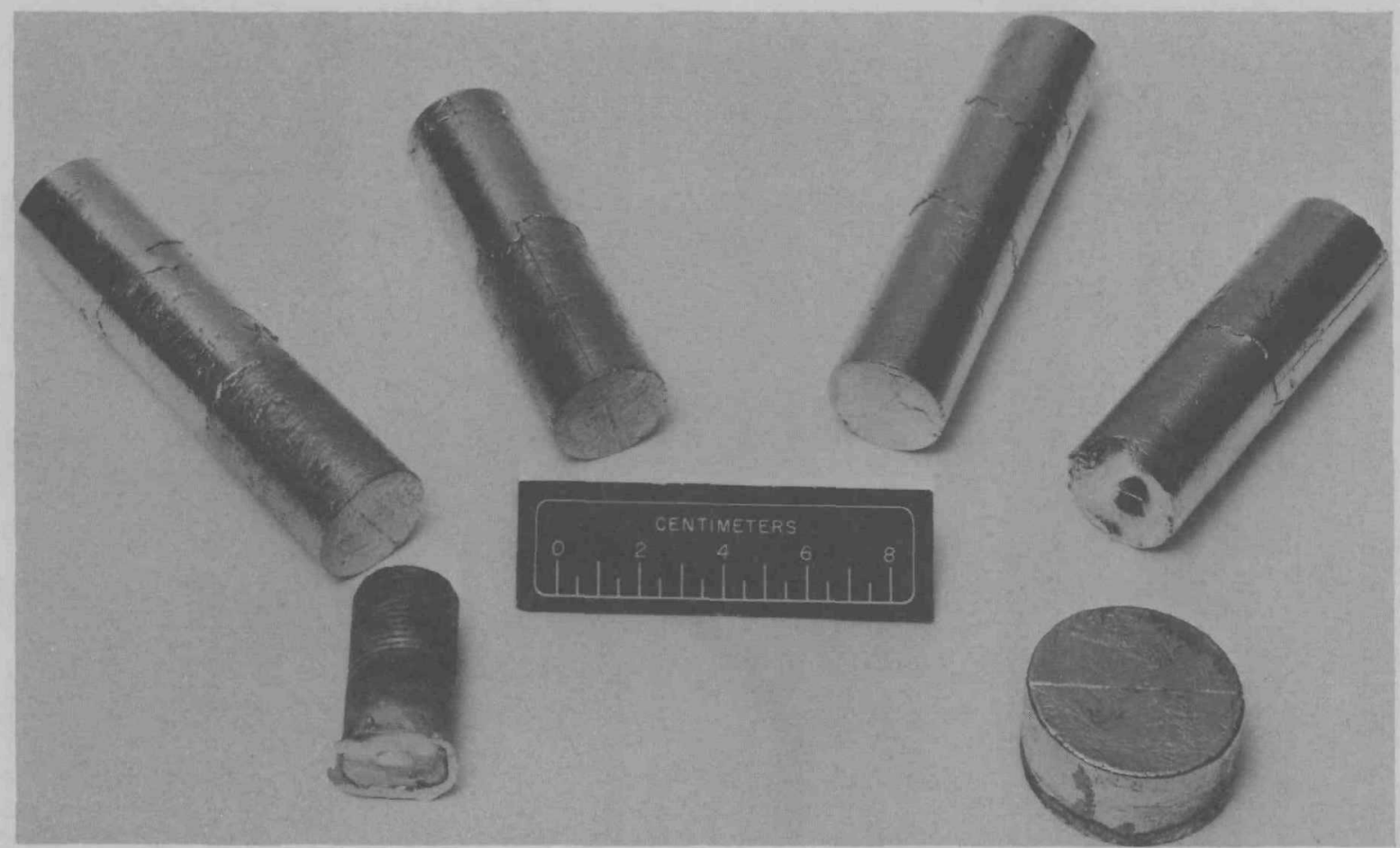

Fig. 3. Arc-melted and drop-cast electrode sections (top four pieces), threaded electrode adaptor (bottom left piece), and striking pad (bottom right piece). 
Figure 4 shows the castings electron beam welded into an electrode. Since one end of each casting is flat, as shown in Fig. 3, only one cut is required to square the remaining end for electron beam welding. The casting at the opposite end from the threaded adapter of Fig. 4 has been left in the untrimmed condition with a rough uneven area to facilitate striking the arc on the pad depicted in Fig. 3. The finished electrode without the threaded adapter weighs approximately $8.0 \mathrm{~kg}$ and is the equivalent of 14 rectangular standard-processed ingots. The operations of head removal, electron beam welding to seal centrally located shrinkage cavity in the top of each casting, and recycling of DOP-26 alloy skull with their accompanying losses for the standard-processed ingots are eliminated, greatly reducing operations required for the consumable arc melting process.

CONSUMABLE ELECTRODE ARC MELTING

B-1 and B-2 electrodes were consumably arc melted into a watercooled copper mold $51 \mathrm{~mm}$ in diameter by $203 \mathrm{~mm}$ deep ( 2 by 8 in.). Melting of B-1 electrode was initiated at $6.7 \mathrm{mPa}\left(5 \times 10^{-5}\right.$ torr $)$ with $1550 \mathrm{~A}$. Current was raised to $3000 \mathrm{~A}$ and melting proceeded to within $50 \mathrm{~mm}$ (2 in.) of the top of the mold or until the electrode had 127 to $150 \mathrm{~mm}$ (5-6 in.) left. The current was then reduced manually to permit filling of the shrinkage cavity until either the solidifying ingot was within approximately $13 \mathrm{~mm}$ ( $0.5 \mathrm{in.})$ of the top of the mold or about $13 \mathrm{~mm}(0.5 \mathrm{in.})$ of electrode was left. The current was then turned of $f$ and the ingot cooled a minimum of $3 \mathrm{~h}$ before removal. The total melting time was approximately $10 \mathrm{~min}$, which is about the time it takes to melt and drop cast one standard-processed ingot.

Y-201268

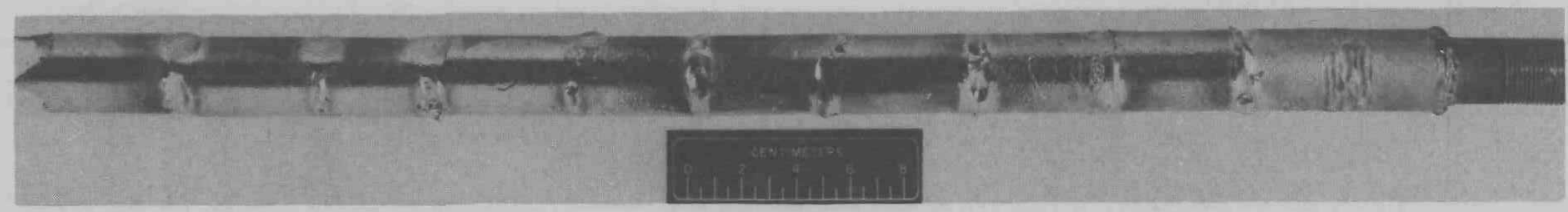

Fig. 4. Electron-beam welded consumable electrode. 
After consumable arc-melting, B-1 casting was trimmed at the top, the striker pad was sawed off and stored for use with B-2 melt, and the resultant B-1 ingot was wire brushed and etched in hot aqua regia. The operation yielded a finished DOP-26 alloy weight of approximately $6.15 \mathrm{~kg}$ for extrusion. The total iridium loss during both melting and trimming operations was approximately $0.14 \mathrm{~kg}$. The B-2 electrode was melted into the B-2 ingot using approximately the same conditions. The B-1 ingot with the pad still in place and remaining portion of its threaded electrode adapter is shown in Fig. 5 .

\section{EXTRUSION}

A schematic of the molybdenum billet for containment of the cast ingot during extrusion is shown in Fig. 6. Since the reduction anticipated for extruding and hot rolling operations normally iron out minor surface discontinuities, the finished iridium ingot, which measured $51 \mathrm{~mm}$ in diameter by $127 \mathrm{~mm}$ long ( 2 by 5 in.) after removal of the pad at bottom and flash at top (see Fig. 5), was inserted into the molybdenum billet without further surface treatment. The molybdenum served to insulate the iridium ingot during extrusion and offered protection against surface contamination. The molybdenum oxide that forms on the outside of the billet provides high-temperature lubrication. The billets to be extruded were consecutively heated in argon for $3 \mathrm{~h}$ at $1200^{\circ} \mathrm{C}$. Rectangular sheet bar dies with a $19-$ by $38-\mathrm{mm}(0.750-$ by $1.50-$ in.) opening were used to give a reduction in area of about $6: 1$. The extrusion time from removal of a billet from the furnace to extrusion through the die required between 20 to $25 \mathrm{~s}$, and therefore permitted only minor cooling to occur. Each extrusion was straightened on a 4.5-MN (500-ton) press while above $1000^{\circ} \mathrm{C}$.

Figure 7 illustrates $\mathrm{B}-1$ and $\mathrm{B}-2$ extrusions. Although both extrusion billets were the same size, there is a difference in cross section and length of the extruded bars, as may be noted in Fig. 7. This was due to the failure of both dies owing to poor fit with the container of the press. The die for the B-1 billet failed by corner cracking early in the extrusion. Severe die wear occurred at the end of extrusion. Figure 8 shows a 


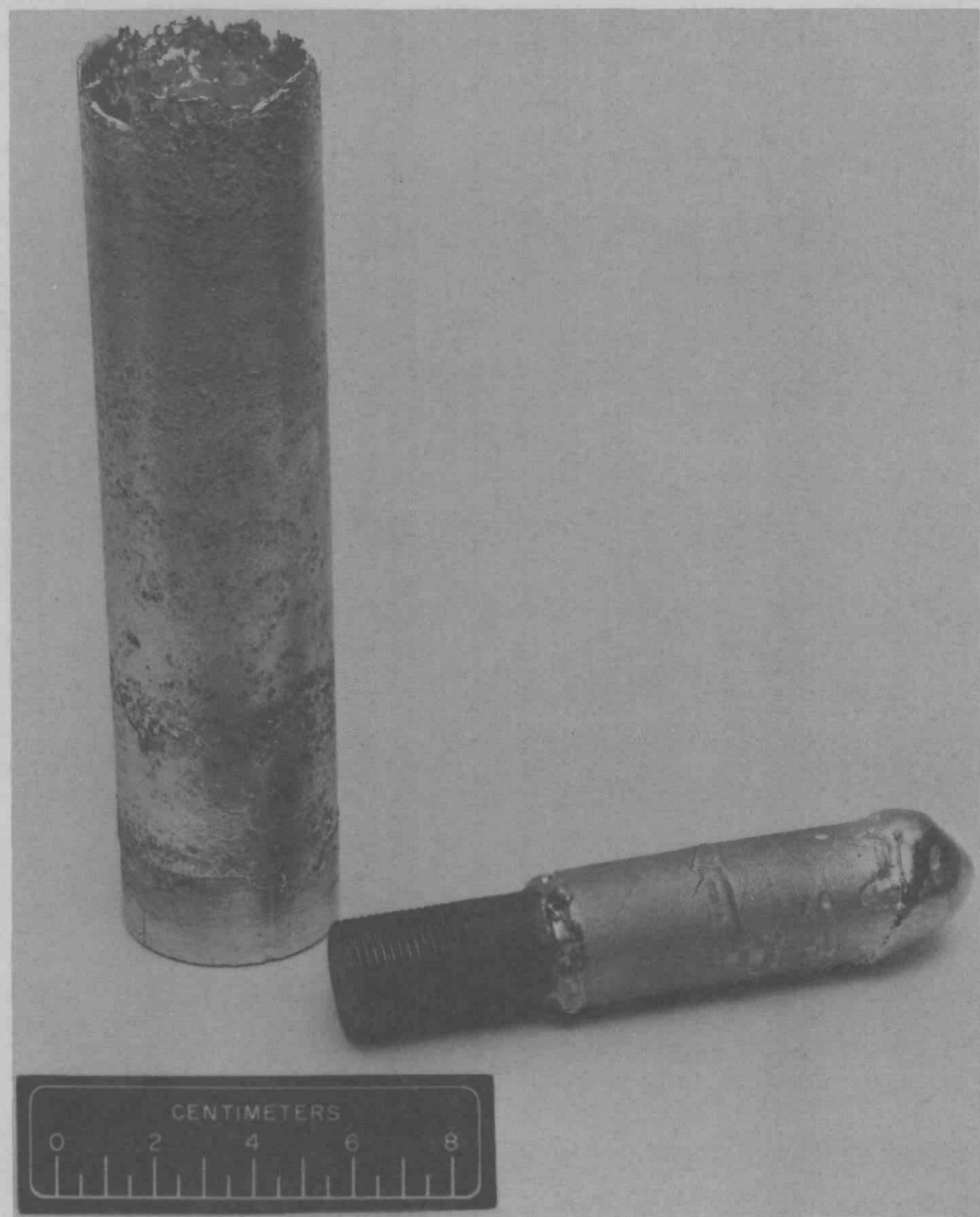

Fig. 5. Consumable arc-melted B-1 ingot on striking pad and electrode stub. 
ORNL-DWG 85-15099

DRILL $48 \mathrm{~mm}(3 / 16$ in.) diam. $\times 4,8 \mathrm{~mm}$ DEEP,

2 HOLES FOR PLUG REMOVAL

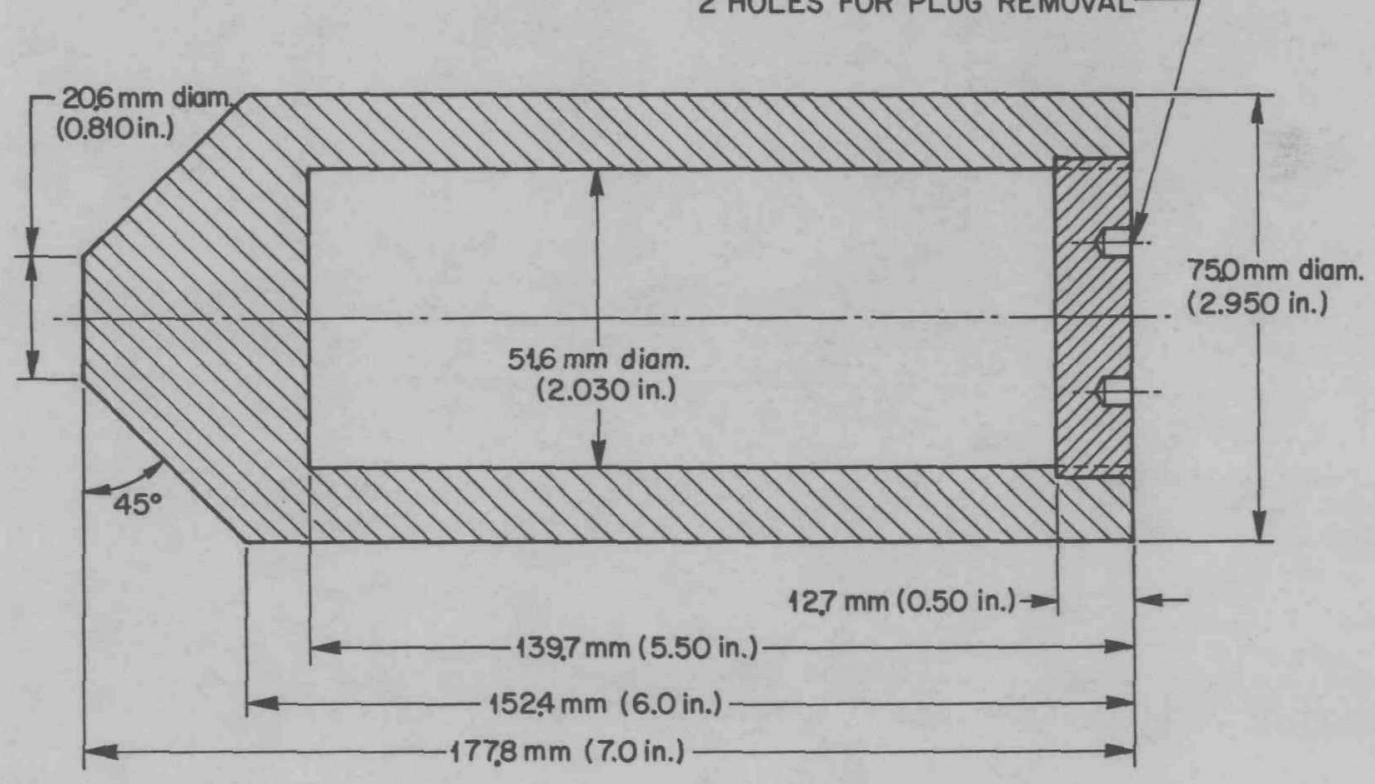

Fig. 6. Molybdenum billet for DOP-26 alloy extrusion.

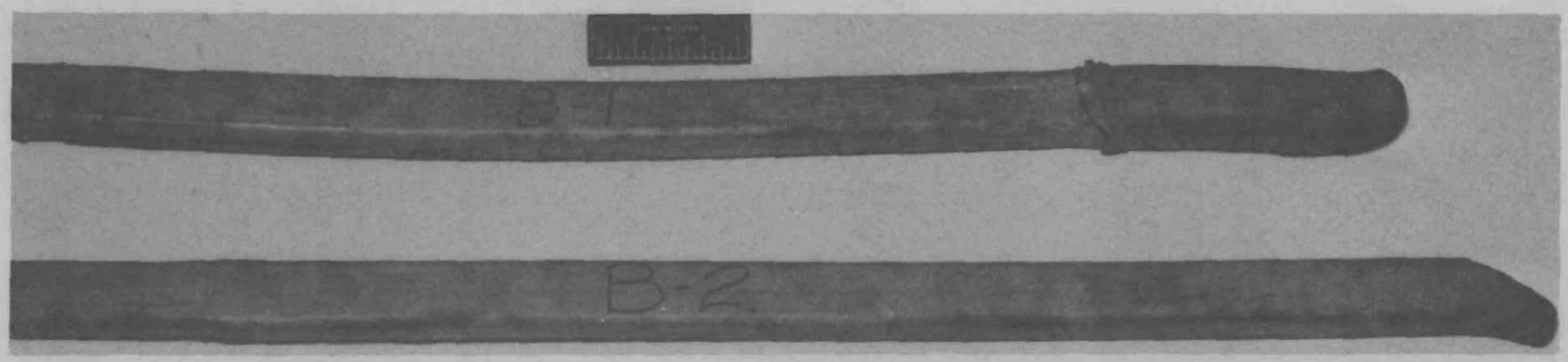

Fig. 7. The B-1 and B-2 extrusions showing molybdenum clad surface. 


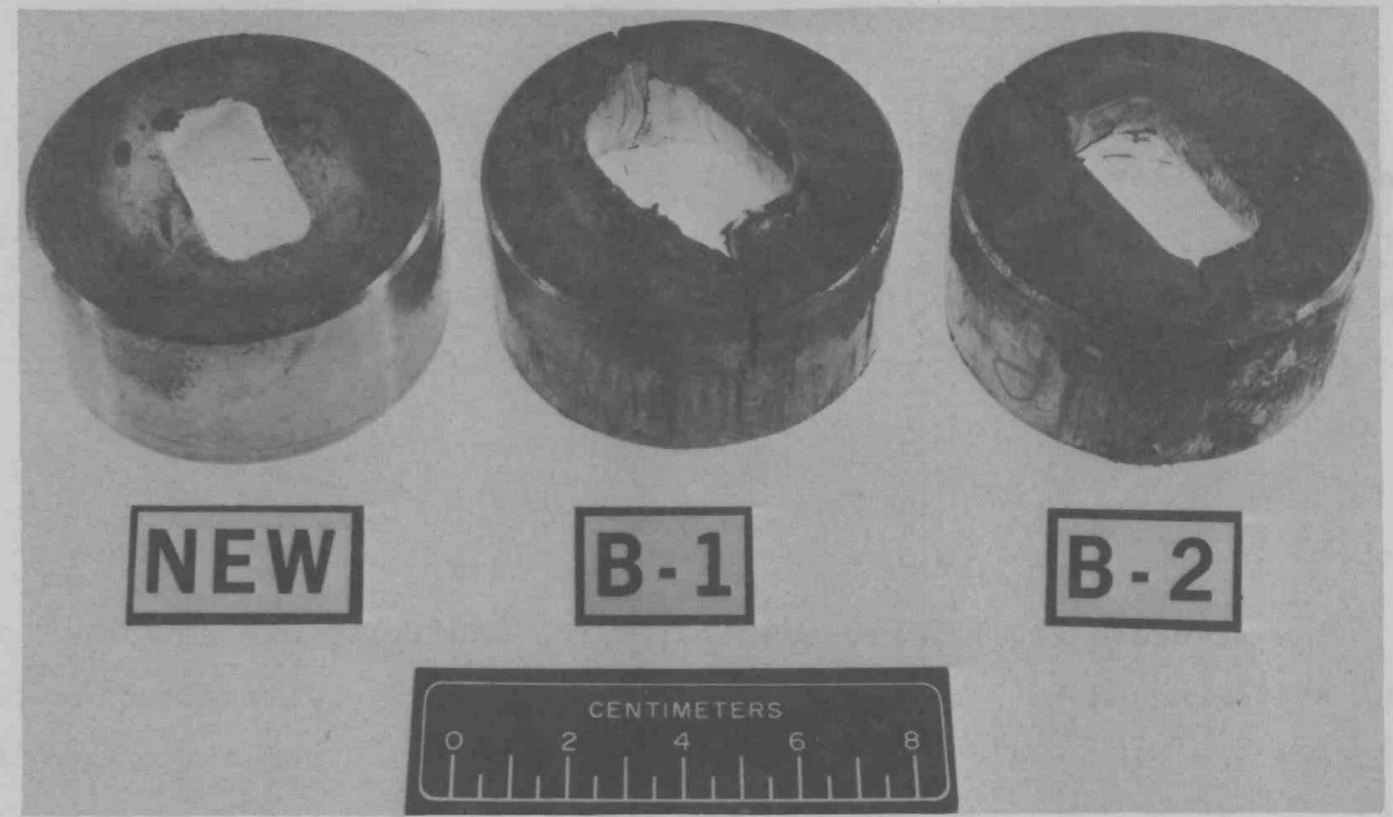

Fig. 8. New extrusion die and failed dies from B-1 and B-2 extrusions.

new die and the failed $\mathrm{B}-1$ and $\mathrm{B}-2$ dies. The extruding pressure for $\mathrm{B}-1$ was $6.2 \mathrm{MN}$ (700 tons), which is approximately the maximum allowable stem load for our 76-mm (3-in.) tooling.

The high extruding pressure and failure of the B-1 die indicated that reduction should be decreased or extruding temperature increased for the B-2 billet. The $1200^{\circ} \mathrm{C}$ temperature, which is also the primary breakdown temperature for rolling cast DOP-26 alloy, was selected to minimize recrystallization of the extruded material. Since it was planned to initiate rolling of the extruded billets at approximately 19-mm (0.750-in.) thickness and additional work would be introduced by rolling prior to recrystallization, the temperature for B-2 billet was increased to $1250^{\circ} \mathrm{C}$, and the B-2 billet heated an additional hour. That is, the B-2 billet was held, along with the B-1 billet, at $1200^{\circ} \mathrm{C}$ for $3 \mathrm{~h}$, and then alone at $1250^{\circ} \mathrm{C}$ for another hour before extrusion. It can be seen in Fig. 8 that the die for the B-2 extrusion shows less cracking and wash due to reduced strength of the DOP-26 alloy at $1250^{\circ} \mathrm{C}$.

The B-2 extrusion shown in Fig. 7 showed only a minor change in cross section, and the extruding pressure was a more reasonable $4.9 \mathrm{MN}$ (550 tons). The molybdenum surface of both extrusions was smooth, and no 
indication of internal failure of the DOP-26 alloy was noted. In clad extrusions, internal cracking is visually evidenced by local reduction or tearing of the clad.

A band saw was used to trim the ends from each extrusion and locate the DOP-26 alloy. It was noted during trimming that the DOP-26 alloy did not bond to the molybdenum and could be readily removed by saw slits in the sides. One section, approximately 76-mm (3-in.) long, was cut from the leading end of each extruded bar for rolling evaluation before cutting up the remainder for rolling billets.

\section{ROLLING}

The standard rolling procedure with the modifications developed in 1984 of increased hot reduction followed by lower recrystallization temperature for consumable arc-cast DOP-26 was used as a guideline to roll billets cut from the $\mathrm{B}-1$ and $\mathrm{B}-2$ extrusions. Neither the standard rolling process nor the 1984 modifications were directly applicable since it was necessary to accommodate the change in geometry from a cast square cross-sectional ingot of $19 \times 19 \times 54 \mathrm{~mm}(3 / 4 \times 3 / 4 \times 21 / 8 \mathrm{in.})$ to an extruded rectangular cross-sectional billet of $17.5 \times 33.3 \times 76 \mathrm{~mm}$ $(0.690 \times 1.310 \times 3 \mathrm{in.})$. Major processing changes included additional reduction at $1200^{\circ} \mathrm{C}$ before recrystallization, lowering the recrystallizing temperature from 1400 to $1300^{\circ} \mathrm{C}$, and increasing the hot finishing temperature from 1000 to $1100^{\circ} \mathrm{C}$. The latter change achieved a more uniform thickness across the sheet than standard-processed material. The uniformity in thickness also reduced tension at the plate edges; that is, no edge cracking was observed in the new process material, whereas old process material required edge trimming to remove cracks.

Four rolling billets from each extrusion, which includes the initial one cut for preliminary rolling experiments and those later cut from both ends and the center of each extrusion, were rolled using the revised process. The sheets were fabricated into forming blanks that we inspected and sampled in accordance with quality assurance procedures for flightquality hardware. Since it was planned that further testing would be conducted at MP, SRP, and LANL, a controlled and documented process was used to produce the blanks from both ingots. Forty-one blanks were obtained from the eight rolled sheets; seven rolling billets are stored for either future use or recycle. 


\section{FABRICATION PROCEDURES}

Fabrication procedures for the new process were prepared based on data obtained from the operations conducted. Standard procedures for powder preparation, electron beam melting and arc melting remained the same. New procedures were prepared for consumable electrode casting, ingot casting by consumable arc melting, extrusion, and rolling. These procedures, when finalized, will be submitted for approval by MP and Department of Energy, Division of Space Applications.

\section{RESULTS AND DISCUSSION}

The following discussion includes metallography examinations conducted to determine the effects of rolling and recrystallization on the microstructure, chemical analyses to determine the distribution of alloying and impurity elements, and nondestructive examinations used for standard flaw detection. Forty-one forming blanks from eight rolled sheets of two DOP-26 alloy ingots were produced to evaluate the experimental fabricating procedures and to characterize the material fabricated by the new experimental process. Comparisons are made to the standard-processed material for flight-quality DOP-26 alloy hardware.

\section{METALLOGRAPHY}

The experimental consumable arc-melted and extruded bar has a hot reduction of $6.26: 1$ in area ( $84 \%$ in area) at the start of hot rolling, whereas the standard ingot is in the as-cast condition. As a result, structure develops differently for the two processes during initial hot rolling.

Figures 9 and 10 show the longitudinal and transverse structure of B-1 bar that was extruded at $1200^{\circ} \mathrm{C}$. The striations in Fig. 9 and patterns on Fig. 10 are assumed to be artifacts of as-cast grain boundaries.

Figure 11 shows the B-1 rolling billet structure after being hot rolled at $1200^{\circ} \mathrm{C}$ to a reduction in thickness of $74 \%$. The artifact boundaries of the cast grains have disappeared and the structure has recrystallized to form fine grains with some cold work. A mixture of 


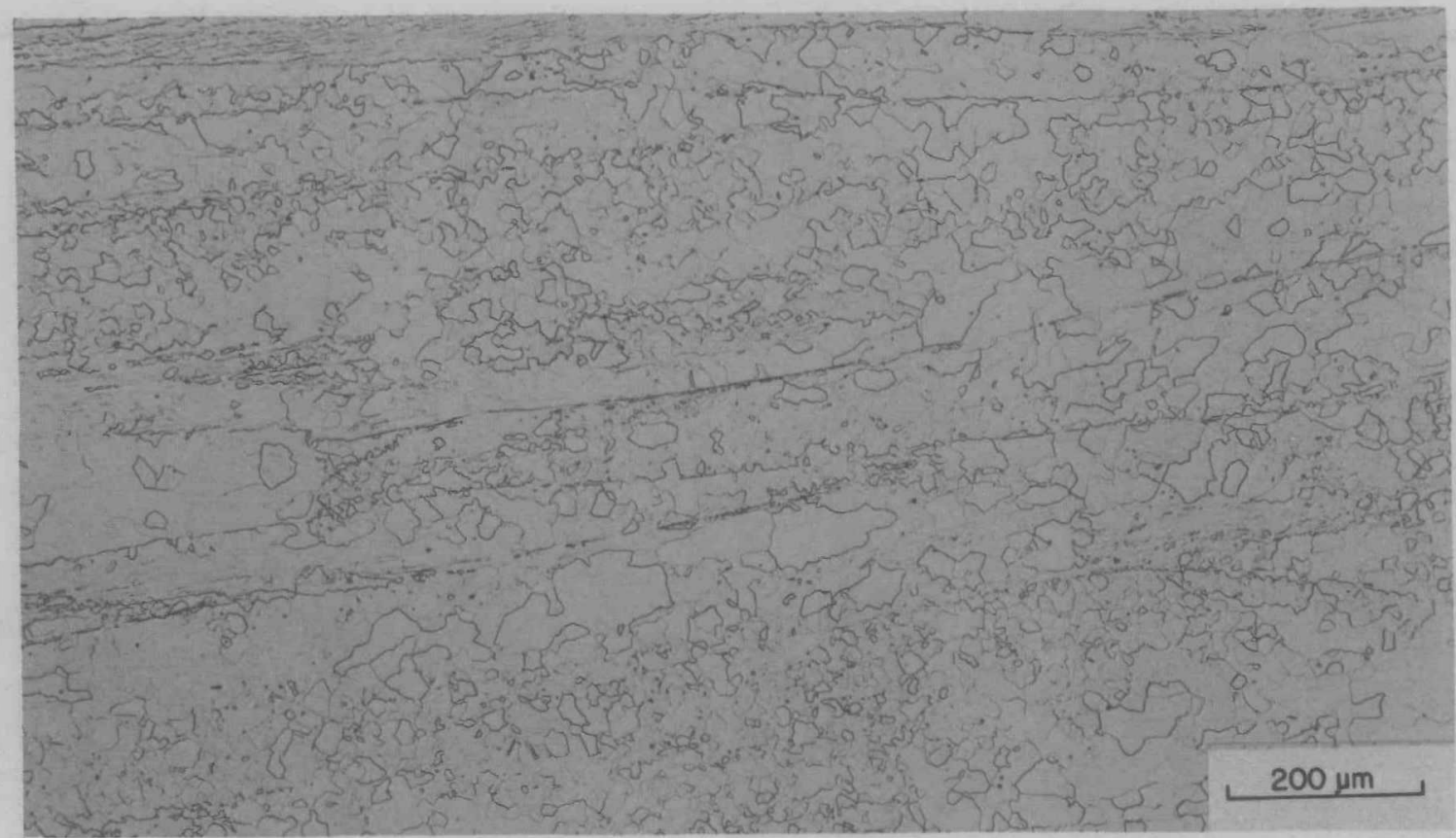

Fig. 9. Longitudinal structure of B-1 bar. The bar was extruded at $1200^{\circ} \mathrm{C}$.

Y-202539

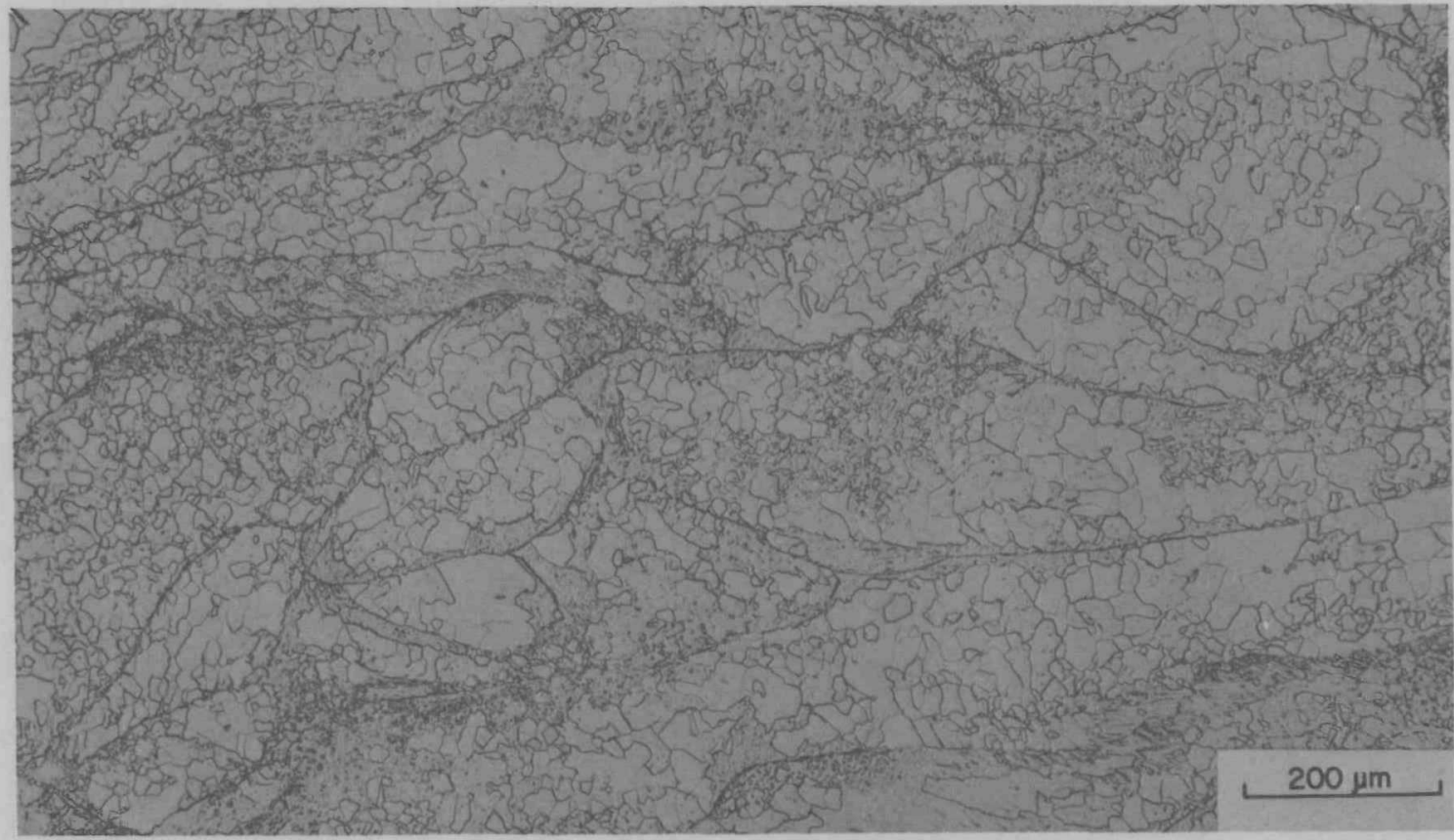

Fig. 10. Transverse structure of B-1 bar. The bar was extruded at $1200^{\circ} \mathrm{C}$. 
Y-202291

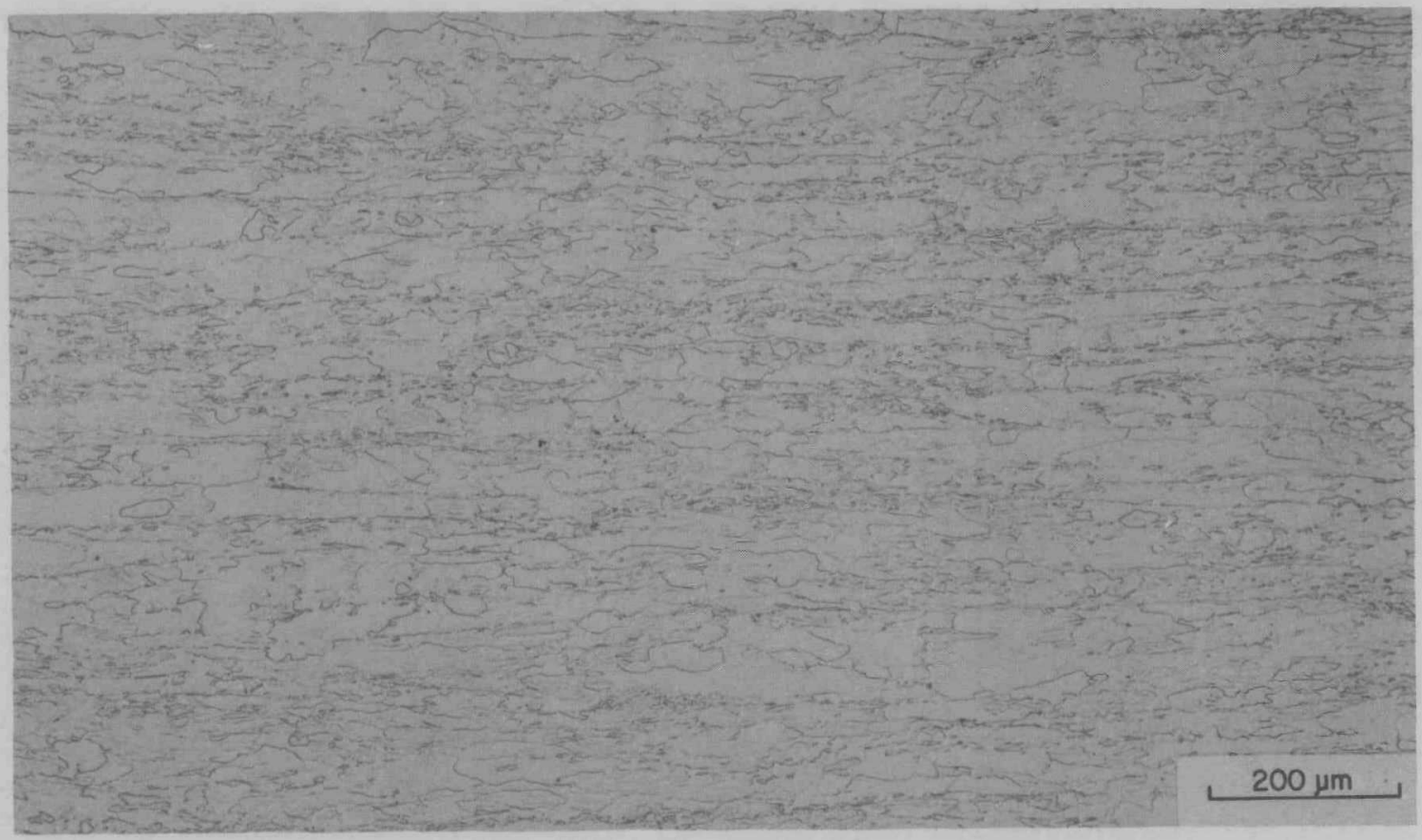

Fig. 11. Longitudinal structure of B-1 rolling billet after being rolled at $1200^{\circ} \mathrm{C}$ to $74 \%$ reduction in thickness .

recrystallized large-grain and cold-worked structures would be observed in standard-processed material at this point. The combination of the high degree of work from the extrusion and the larger rolling billet size (which would maintain rolling temperature) promoted the recrystallization of fine grains. Figure 12 illustrates the longitudinal structure of this billet rolling at $1200^{\circ} \mathrm{C}$ and recrystallizing for $1 \mathrm{~h}$ at $1300^{\circ} \mathrm{C}$. The grains are now more equiaxed with a slight increase in size.

The B-2 consumable, arc-cast ingot was extruded at a higher temperature of $1250^{\circ} \mathrm{C}$. As shown in Fig. 13, the resultant structure of the B-2 bar has a larger grain size than the B-1 bar in Fig. 9, and it also has few small grains. The transyerse, as-extruded structure for the B-2 bar in Fig. 14, however, was quite similar to the transverse, as-extruded structure of the B-1 bar of Fig. 10. Although the extruding temperature was increased by $50^{\circ} \mathrm{C}$, the $\mathrm{B}-2$ bar contained the striations in the longitudinal section and the patterns of the cast grains that the B-1 bar exhibited. 


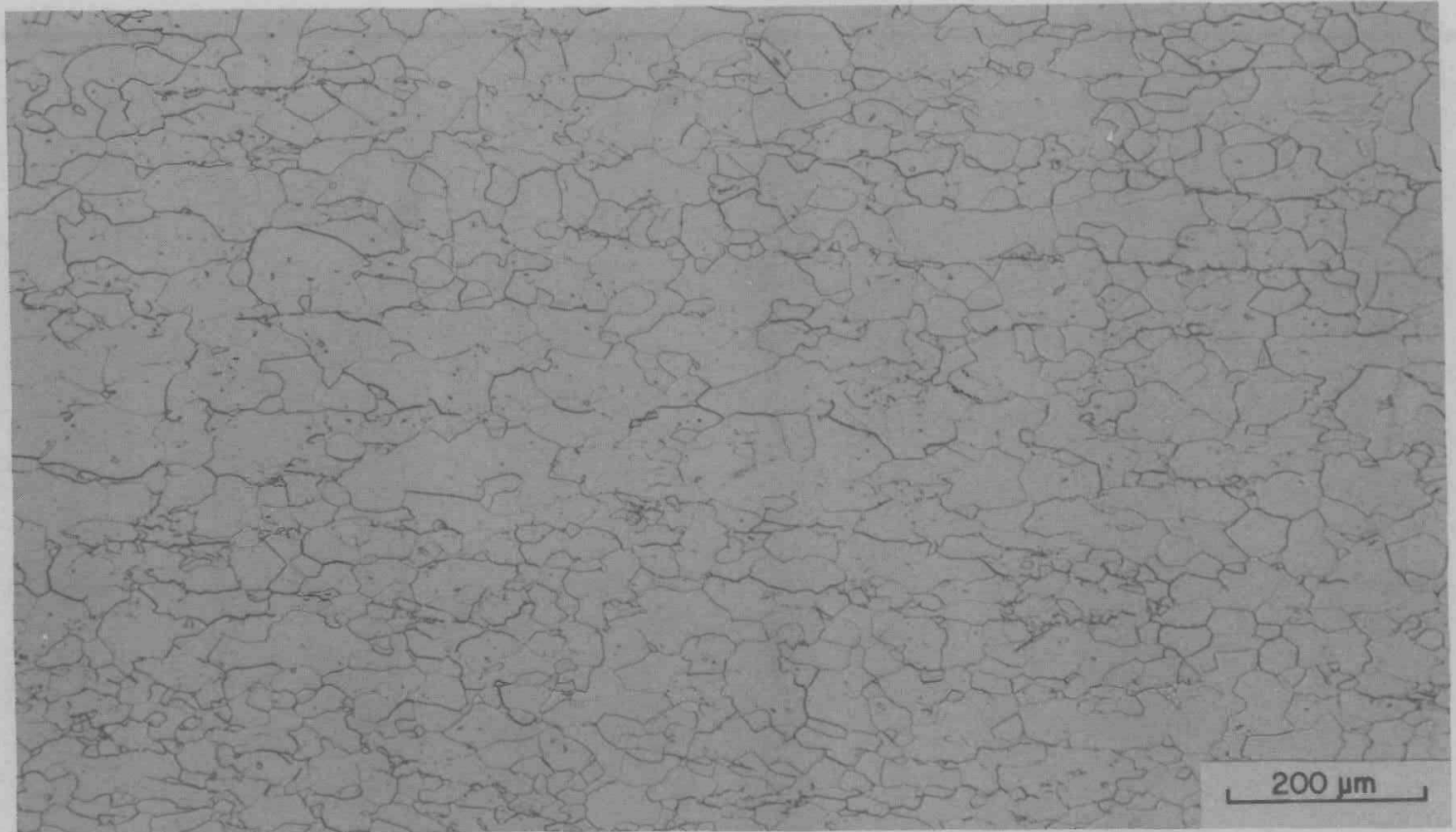

Fig. 12. Longitudinal structure of B-1 rolling billet after being rolled at $1200^{\circ} \mathrm{C}$ to $74 \%$ reduction in thickness and then annealed for $1 \mathrm{~h}$ at $1300^{\circ} \mathrm{C}$.

Y-202540

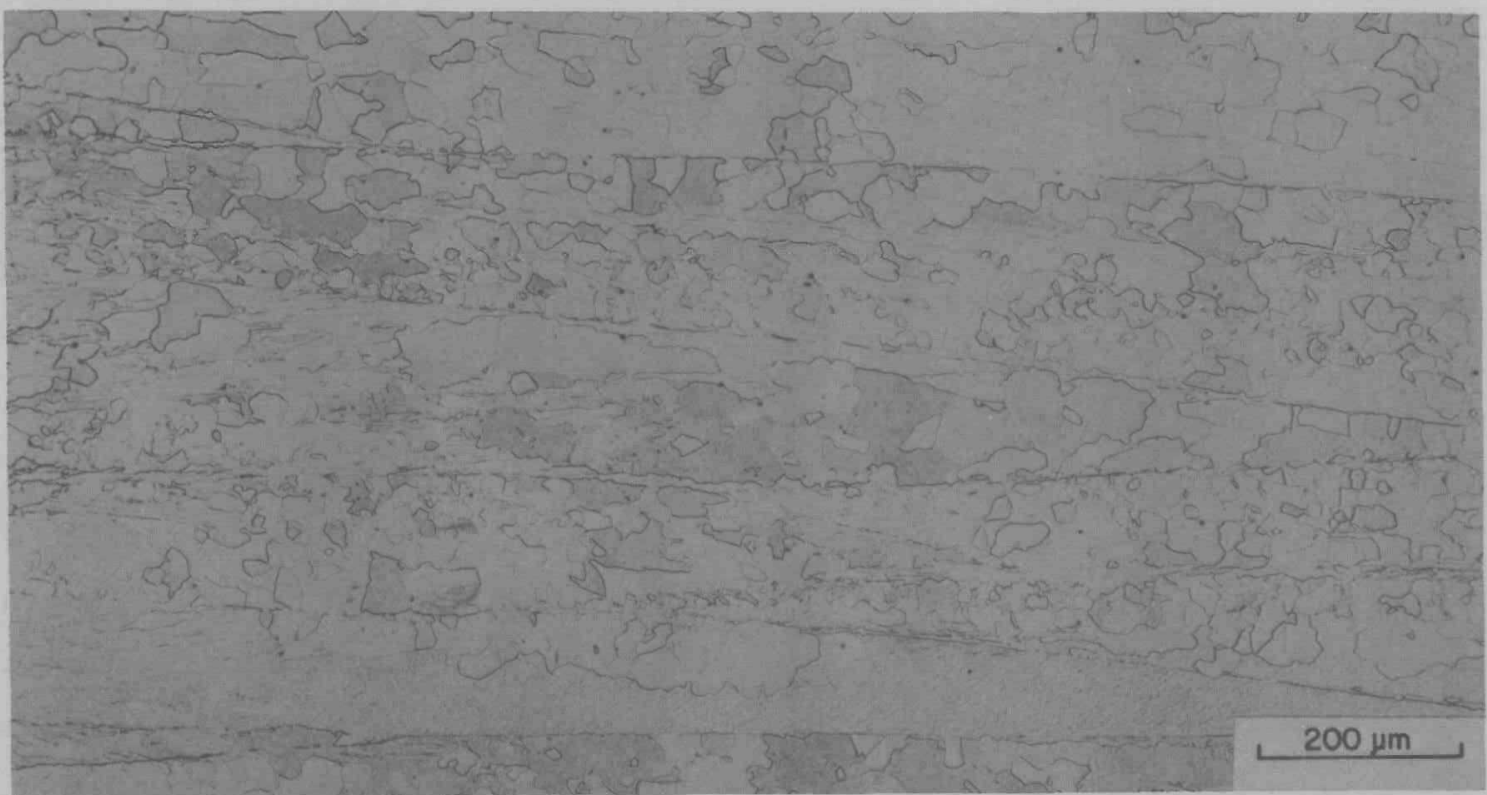

Fig. 13. Longitudinal structure of $B-2$ bar that was extruded at $1250^{\circ} \mathrm{C}$. 


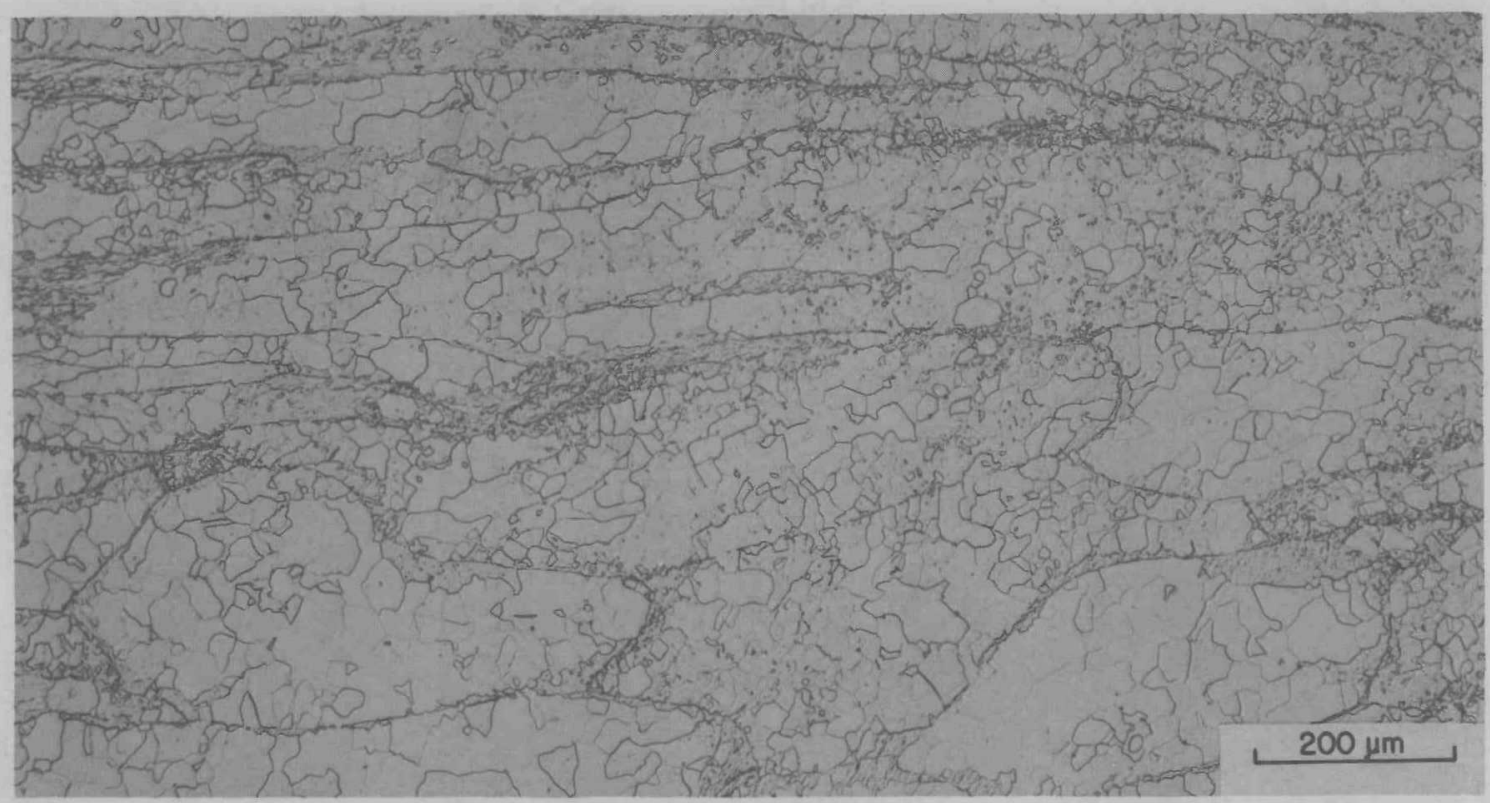
$1250^{\circ} \mathrm{C}$.

Fig. 14. Transverse structure of $\mathrm{B}-2$ bar that was extruded at

Figure 15 shows the B-2 rolling billet structure after being hot rolled at $1200^{\circ} \mathrm{C}$ to a reduction in thickness of $74 \%$. Again, as with the B-1 rolling billet, evidence of the cast grain structure has disappeared and some cold work remained. However, the recrystallized grain size is slightly larger than B-1. In Fig. 16, on annealing at $1300^{\circ} \mathrm{C}$ for $1 \mathrm{~h}$, the structure was also completely recrystallized to produce a grain size similar to that found in $\mathrm{B}-1$.

The similarity of the grain size and morphology of both B-1 and B-2 rolling billets after recrystallization at $1300^{\circ} \mathrm{C}$ indicates that the extruding temperature difference of $50^{\circ} \mathrm{C}$ had minimal affect on their structures. Moreover, the recrystallizing temperature after primary breakdown has been successfully lowered from $1400^{\circ} \mathrm{C}$ for the standard processed material to $1300^{\circ} \mathrm{C}$ for the modified process. To illustrate this point, compare Figs. 12 and 16 for the B-1 and B-2 materials and Fig. 17 for the standard-processed material. The B-1 and B-2 materials possess a more uniform grain size and less striated grain structure than the standard-processed material. 
Y-202292

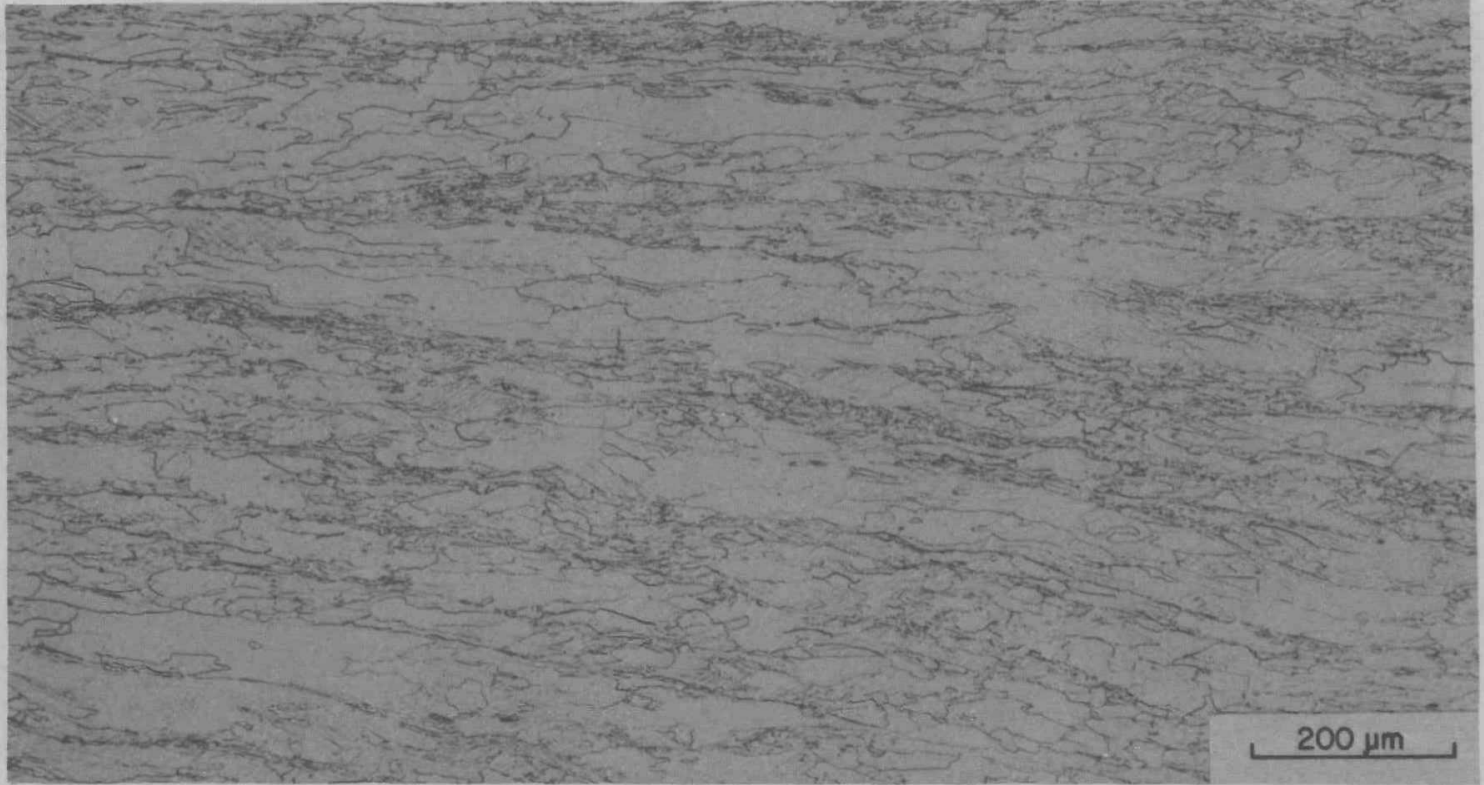

Fig. 15. Longitudinal structure of B-2 rolling billet after being rolled at $1200^{\circ} \mathrm{C}$ to $74 \%$ reduction in thickness.

Y-202295

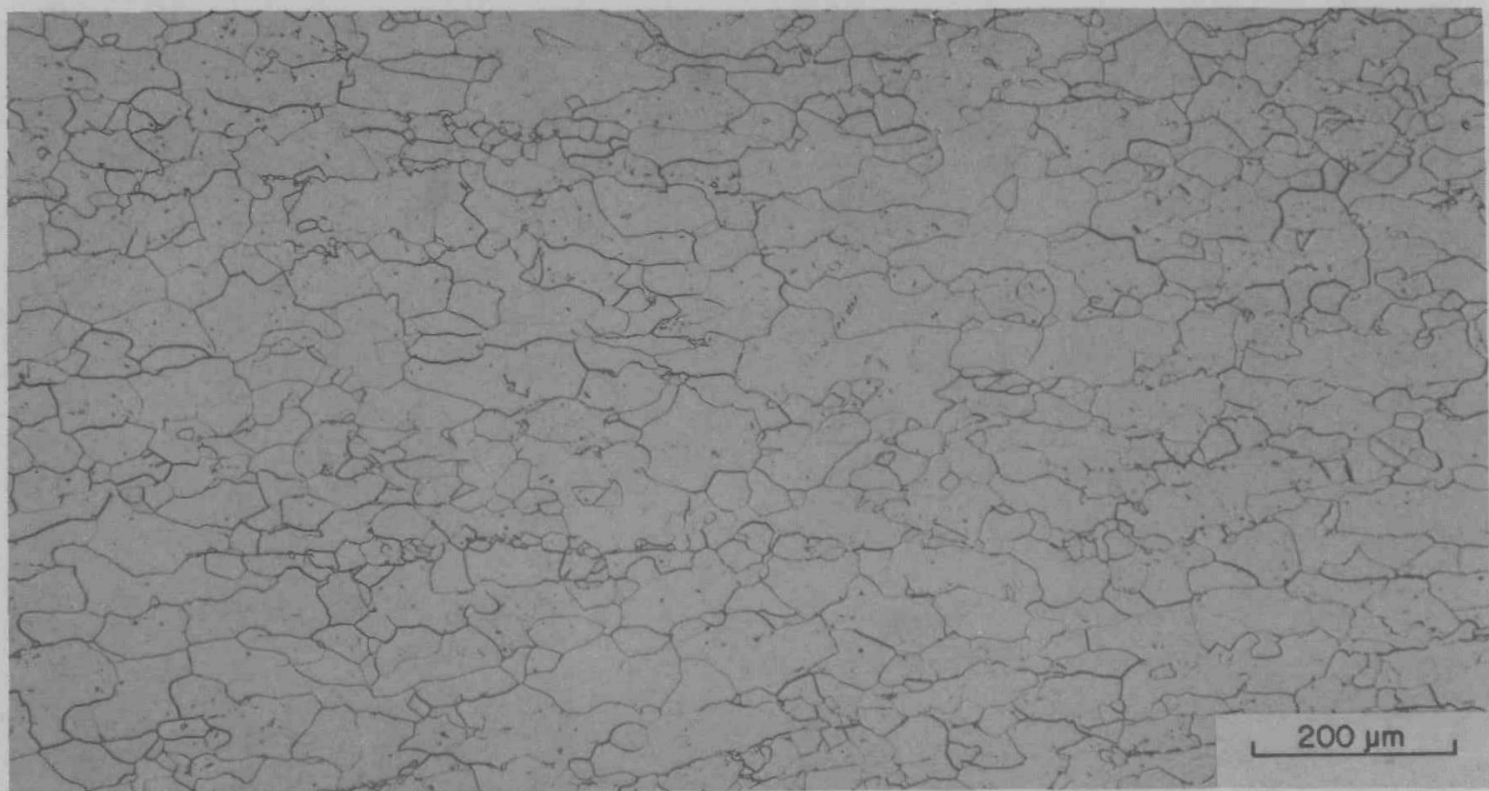

Fig. 16. Longitudinal structure of $\mathrm{B}-2$ rolling billet after being rolled at $1200^{\circ} \mathrm{C}$ to $74 \%$ reduction in thickness and then annealed for $1 \mathrm{~h}$ at $1300^{\circ} \mathrm{C}$. 


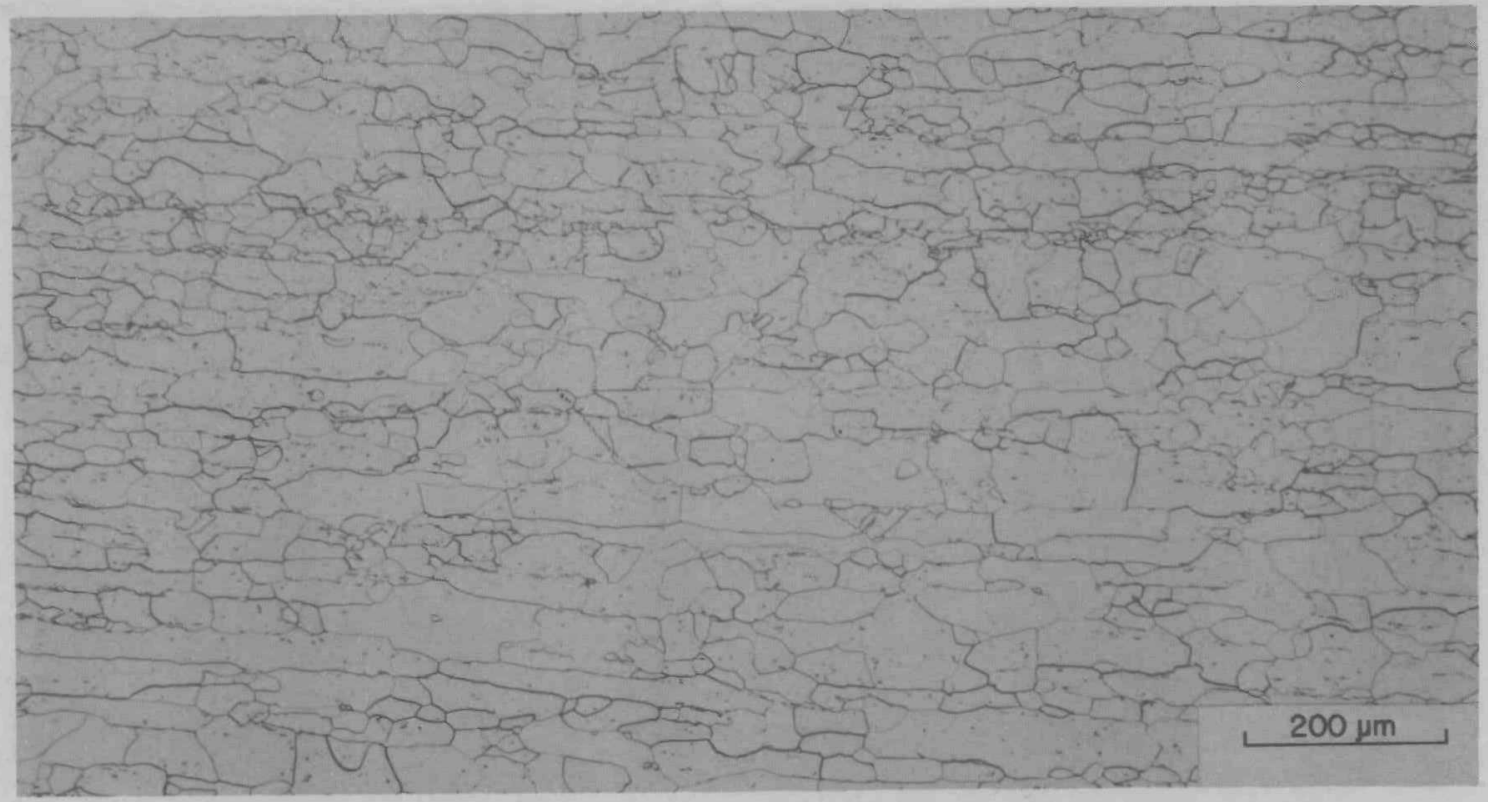

Fig. 17. Longitudinal structure of a B-batch standard-processed DOP-26 alloy ingot after being hot rolled at $1200^{\circ} \mathrm{C}$ to $74 \%$ reduction in thickness and annealed for $1 \mathrm{~h}$ at $1300^{\circ} \mathrm{C}$.

Figures 18 through 20 document the as-rolled microstructures of the finished sheets from the nose (B1-1, B2-1), center (B1-4, B2-5), and tail (B1-7, B2-8) of each extrusion. Essentially no significant differences in structure were observed between the two extrusions or at different locations within the same extrusion.

The photomicrographs of Figs. 18 through 20 may be compared to our metallographic standard that is used to qualify sheet for allowable recrystallization shown in Fig. 21. The structure of the new-processed material exhibits more uniformity than the standard, which permits $5 \%$ recrystallization. The lesser thickness of the standard in Fig. 21 corresponds to that of a ground blank, whereas Figs. 18 through 20 depict the sheets before grinding to size.

The recrystallization and grain growth behavior of the new-processed DOP-26 alloy is important as a larger grain size will adversely affect impact properties. 5 Figure 22 shows a representative microstructure from extruded and rolled new process sheet that has been recrystallized for $1 \mathrm{~h}$ at $1300^{\circ} \mathrm{C}$. 
Y-202542

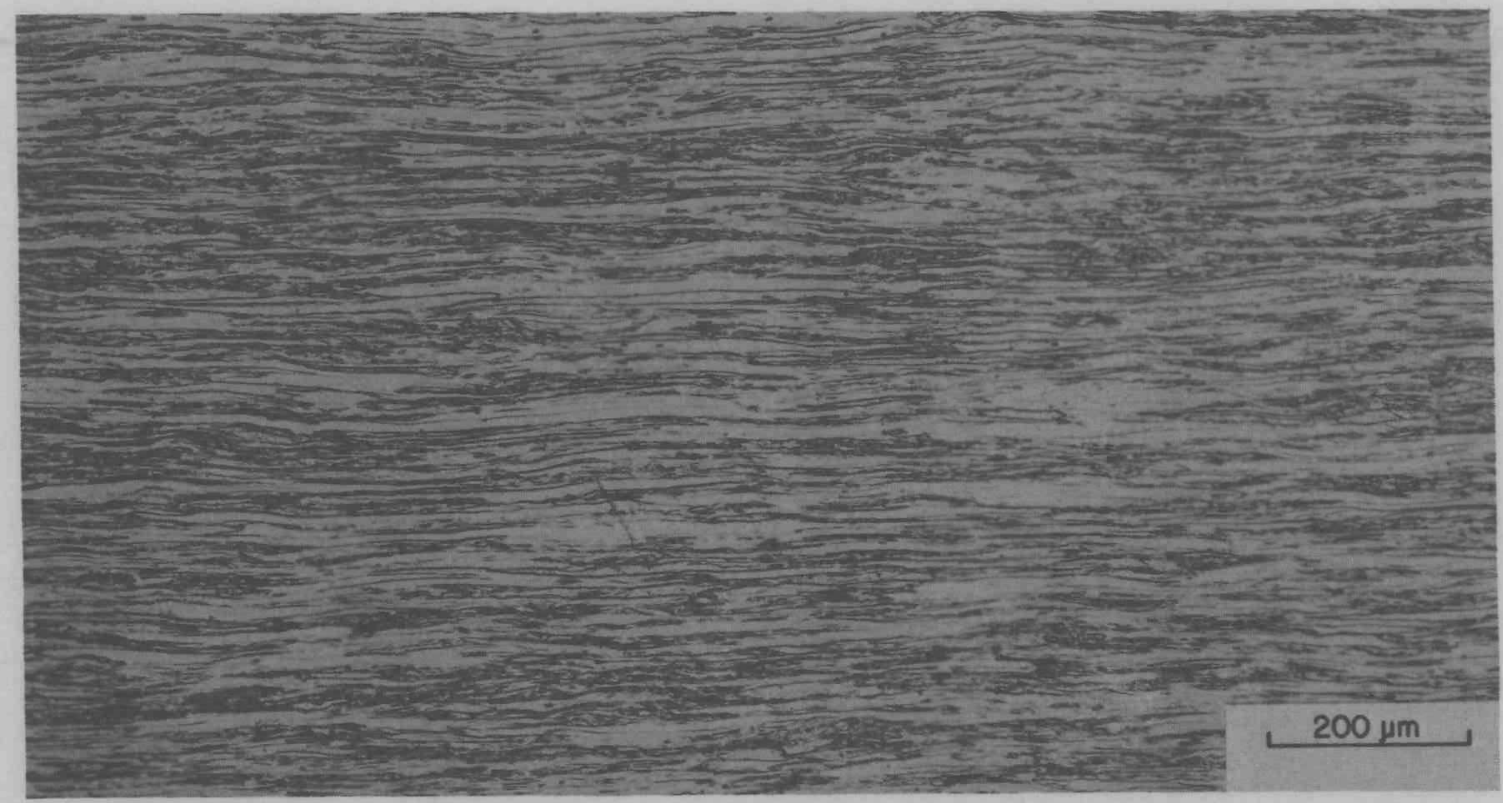

Fig. 18(a). Longitudinal structure of as-rolled B1-1 sheet from nose portion of the $\mathrm{B}-1$ extrusion.

Y-202545

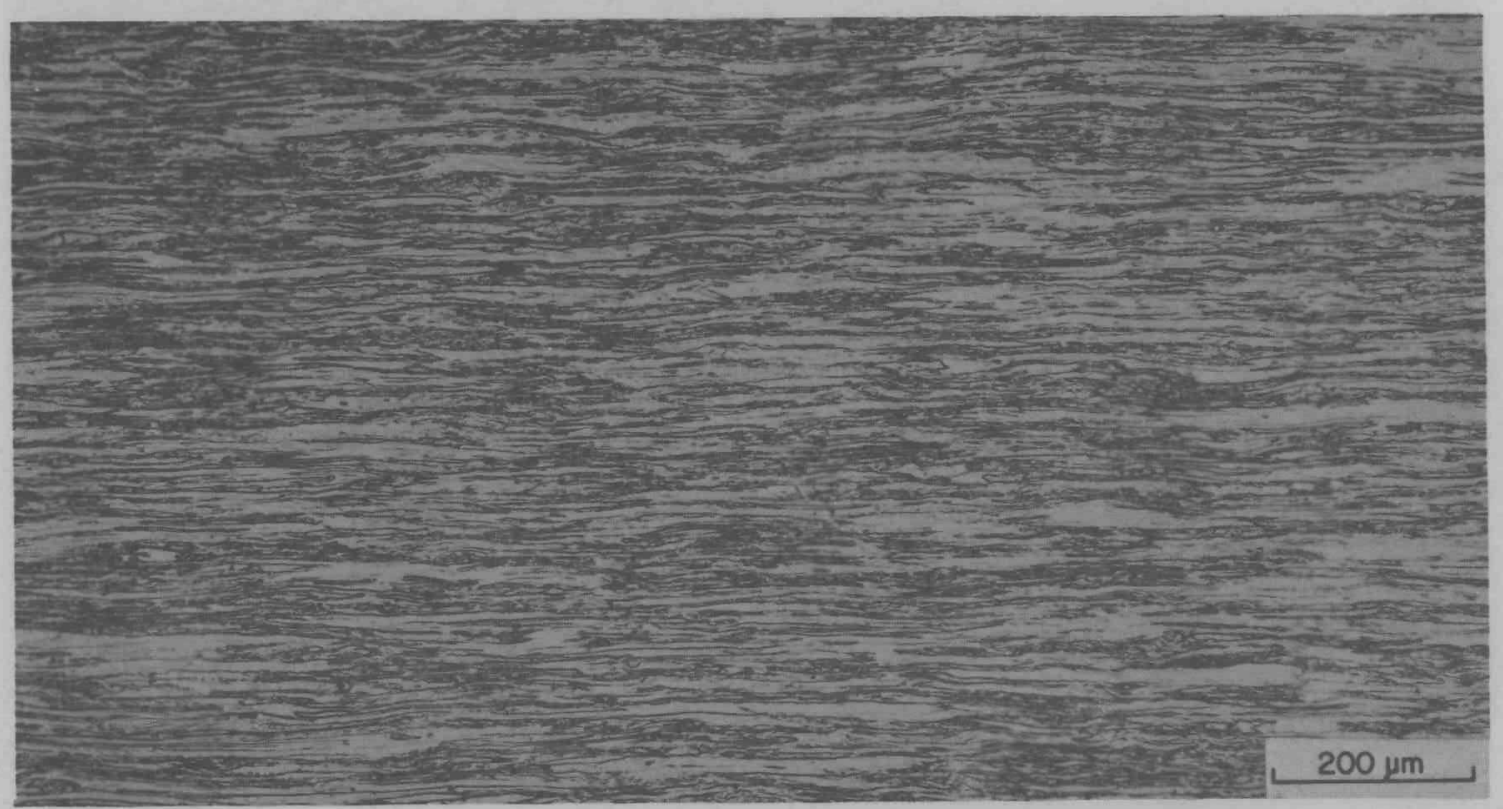

Fig. 18(b). Longitudinal structure of as-rolled B2-1 sheet from nose portion of the $\mathrm{B}-2$ extrusion. 


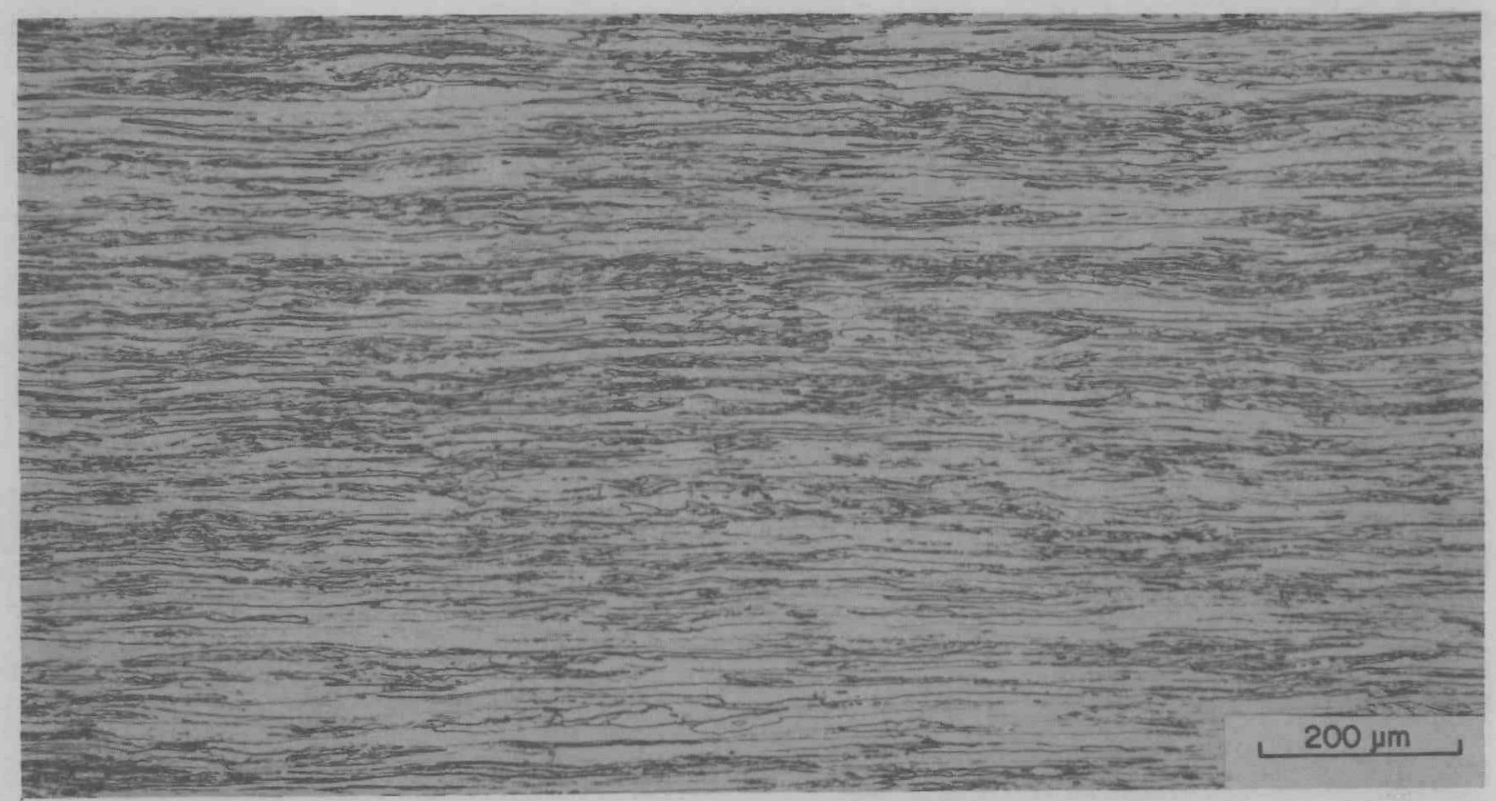

Fig. 19(a). Longitudinal structures of as-rolled B1-4 sheet from central region of the $\mathrm{B}-1$ extrusion.

Y-202546

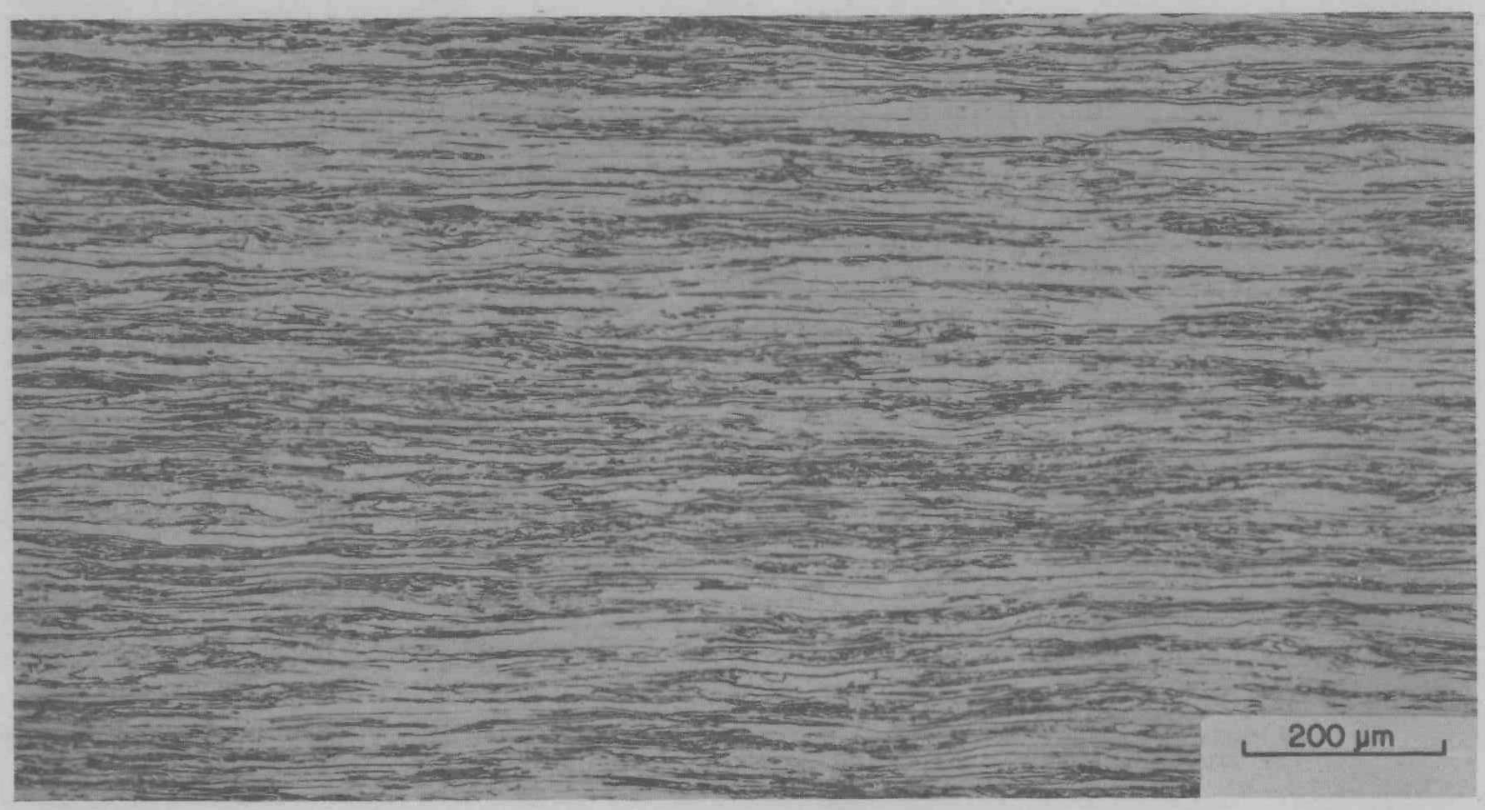

Fig. 19(b). Longitudinal structures of as-rolled B2-5 sheet from central region of the $B-2$ extrusion. 
Y-202544

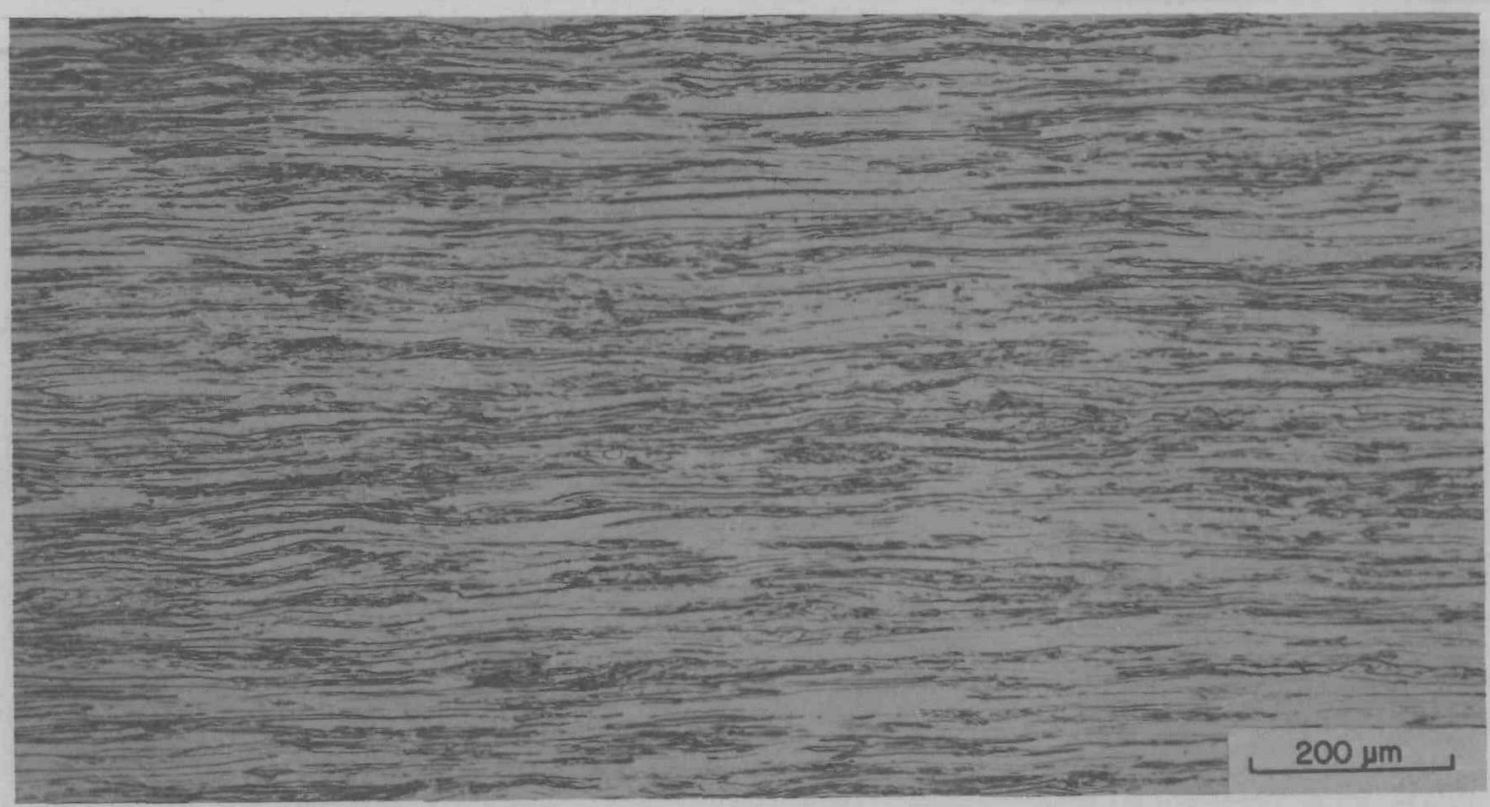

Fig. $20(a)$. Longitudinal structures of as-rolled B1-7 sheet from tail region of the $B-1$ extrusion.

Y-202547

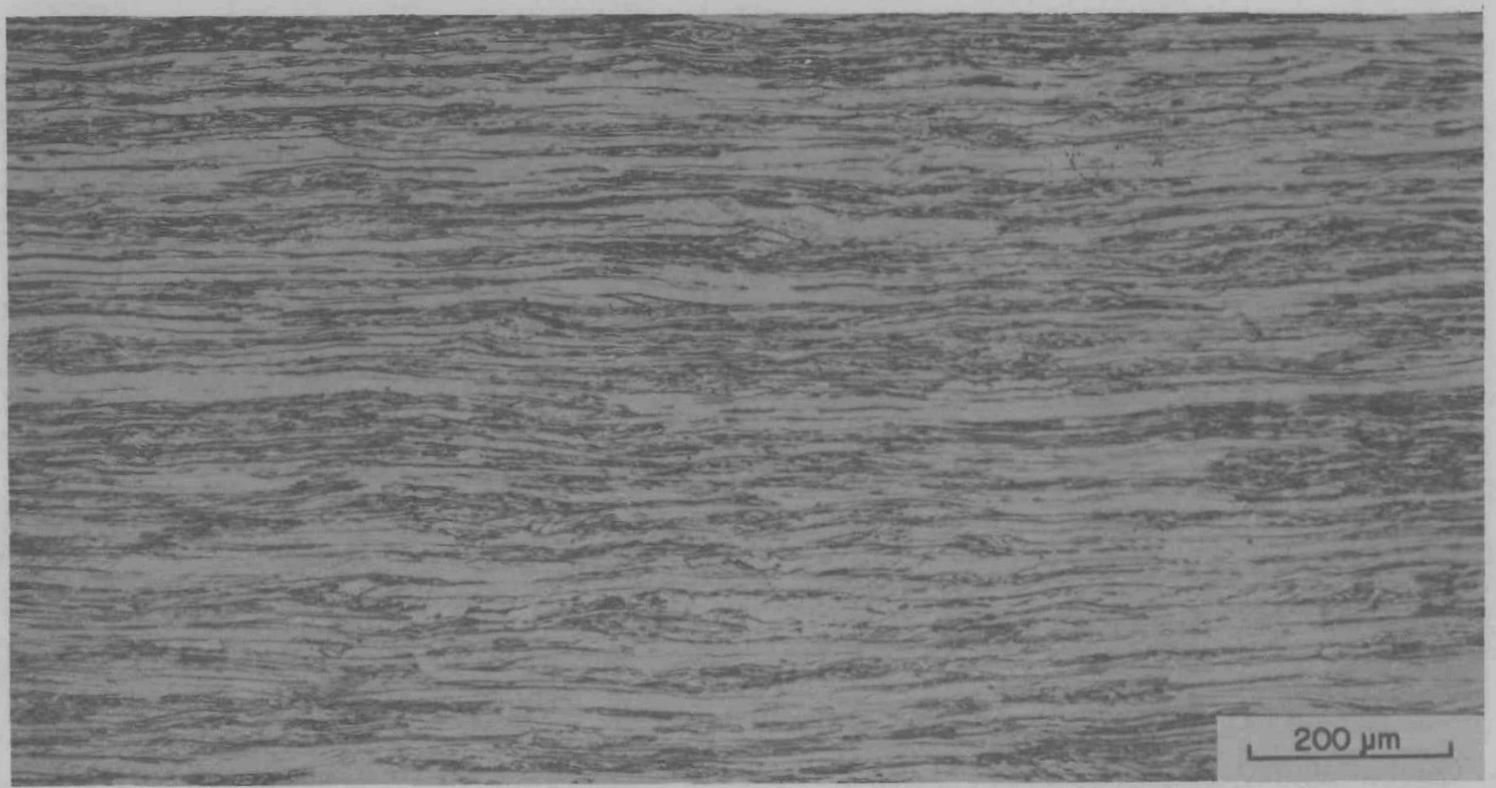

Fig. $20(b)$. Longitudinal structures of as-rolled B2-8 sheet from tail region of the $\mathrm{B}-2$ extrusion. 


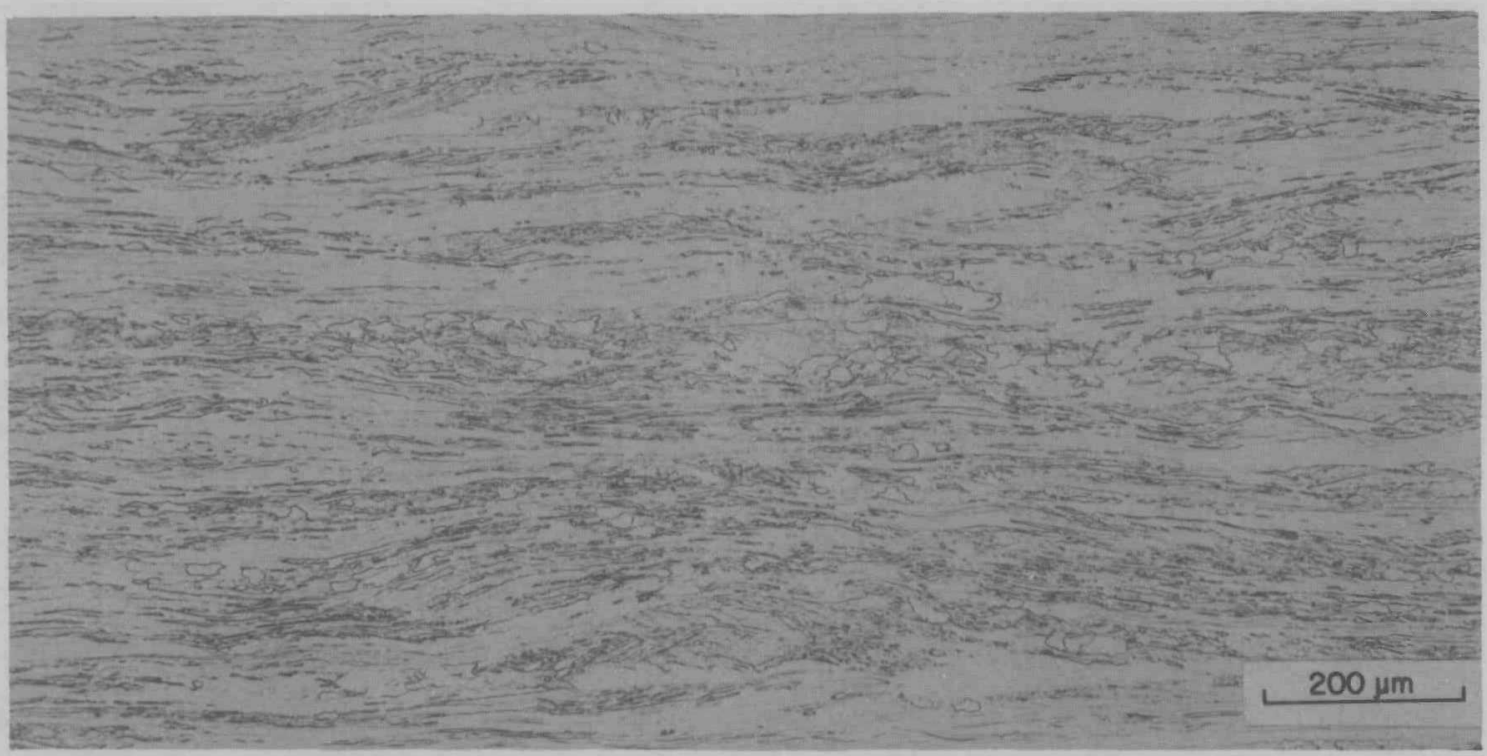

Fig. 21. Longitudinal structure of DOP-26 alloy standard showing maximum permissible recrystallization of $5 \%$ of depicted area of sheet.

Y-202595

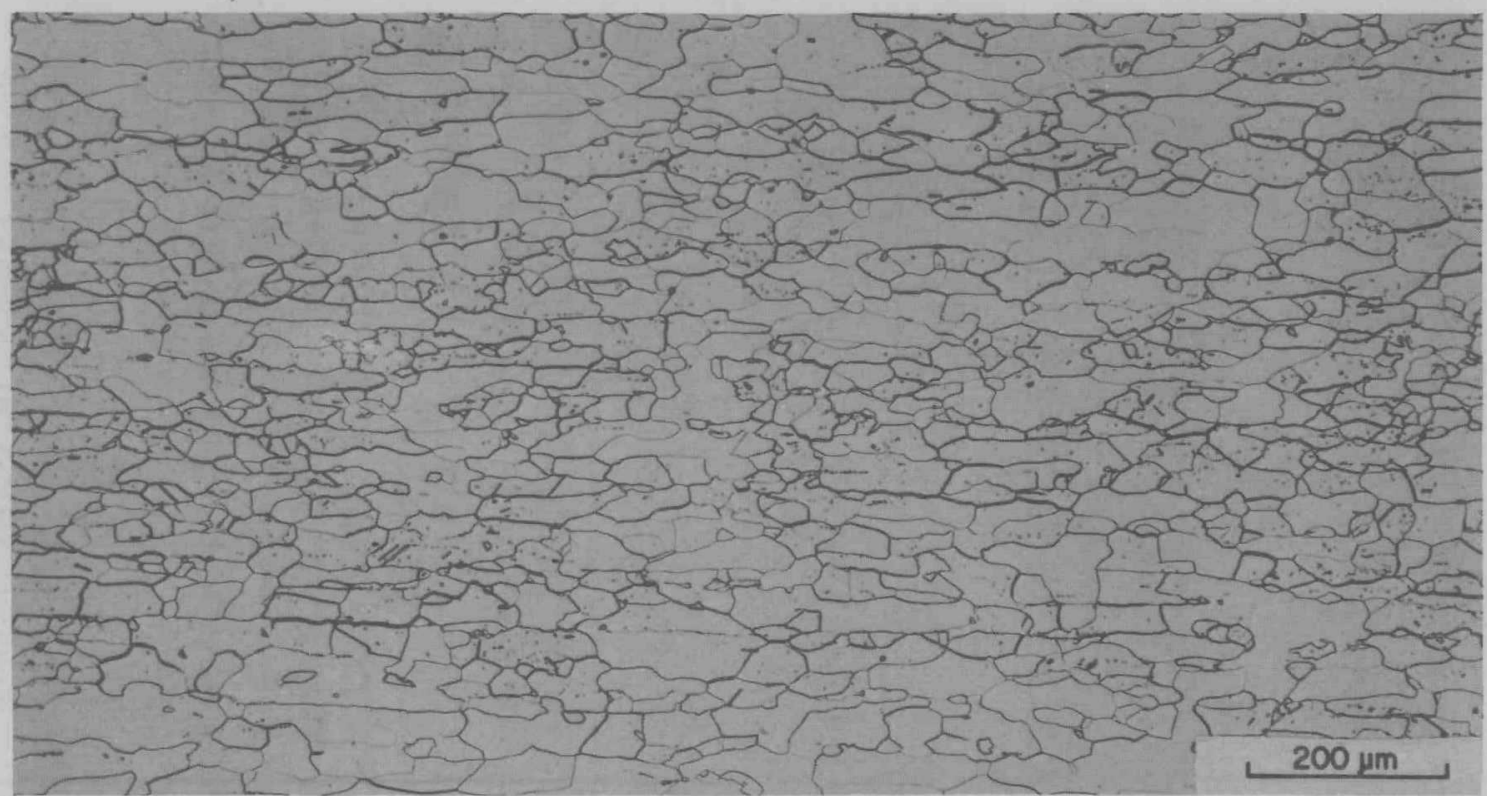

Fig. 22. Longitudinal structure of new-processed sheet recrystallized $1 \mathrm{~h}$ at $1300^{\circ} \mathrm{C}$. 
The grains show the anticipated elongation in the rolling direction that is the typical appearance of the standard-processed sheet. Figure 23 shows the structure for a $1-h$ recrystallization of standard processed sheet at $1500^{\circ} \mathrm{C}$. The new processed sheet recrystallized $1 \mathrm{~h}$ at $1500^{\circ} \mathrm{C}$ shown in Fig. 24 revealed a more equiaxed grain than the standard processed sheet shown in Fig. 23. Faint grain boundaries and stringer distribution indicate that adjacent parallel grains are growing into neighboring grains. And finally, Fig. 25 shows the structure for a 19-h recrystallization at $1500^{\circ} \mathrm{C}$. At this condition, equiaxed grains almost entirely encompass the stringers.

The evident monotony of Figs. 18 through 20 and the expected recrystallizing and grain growth behavior in Figs. 23 through 25 emphasize a significant result in this section on metallography. That is, the asrolled and heat-treated structures revealed little, if any, differences with regard to the extruding temperatures or the nose, central, and tail locations of the two individual extrusions.

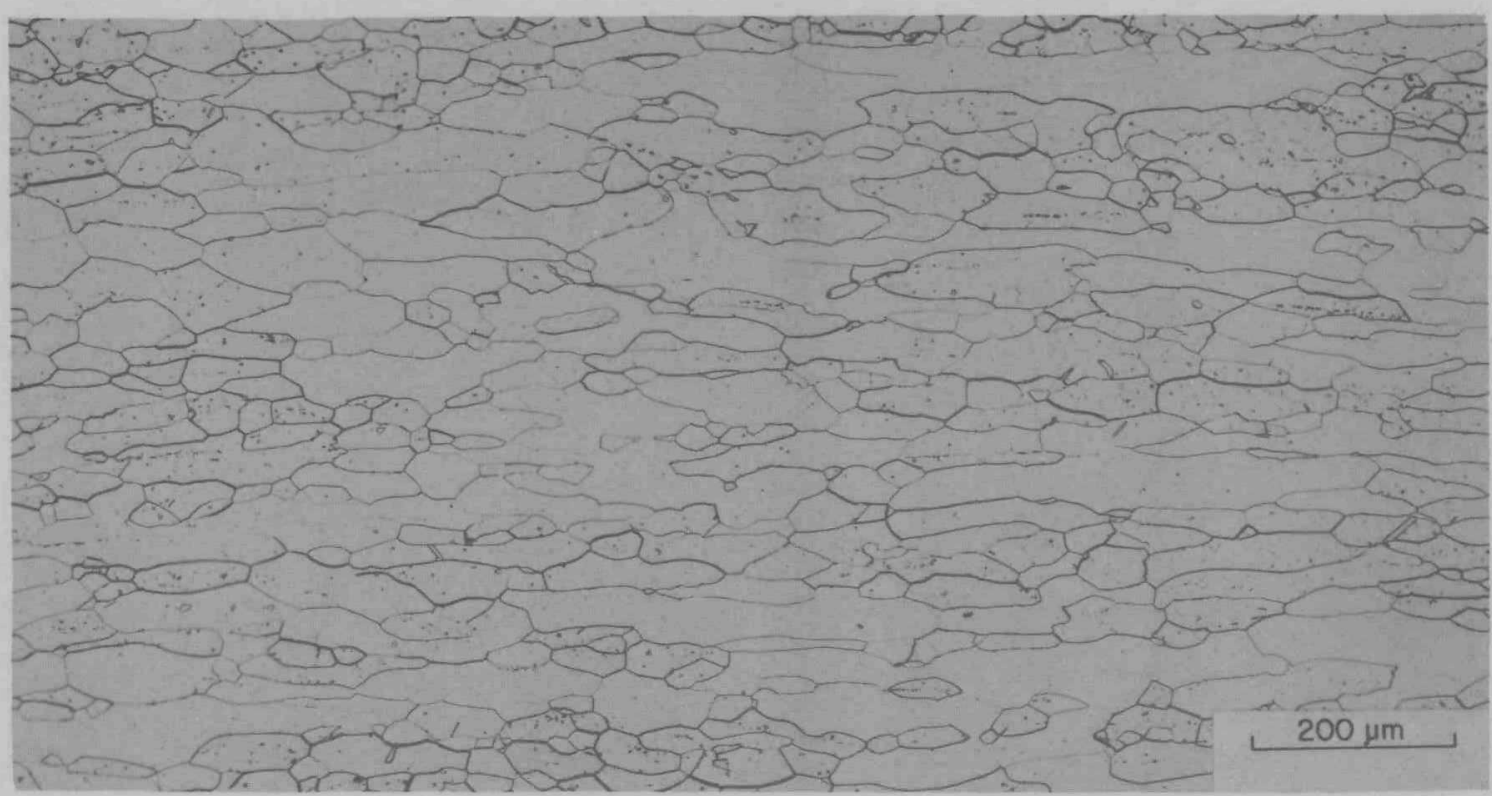

Fig. 23. Longitudinal structure of standard-processed sheet recrystallized for $1 \mathrm{~h}$ at $1500^{\circ} \mathrm{C}$. 
Y-202548

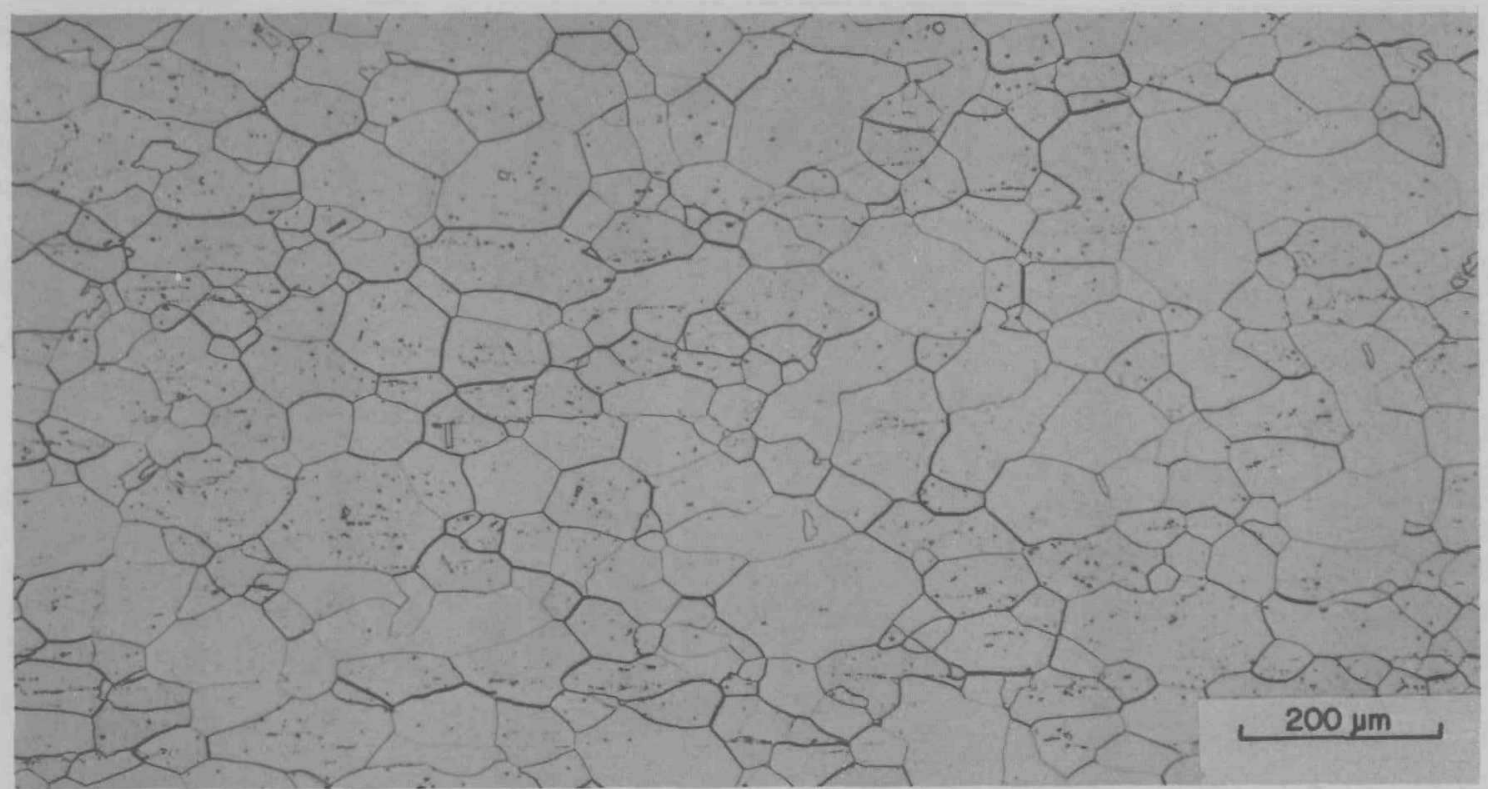

Fig. 24. Longitudinal structure of new-processed sheet recrystallized for $1 \mathrm{~h}$ at $1500^{\circ} \mathrm{C}$.

Y-202599

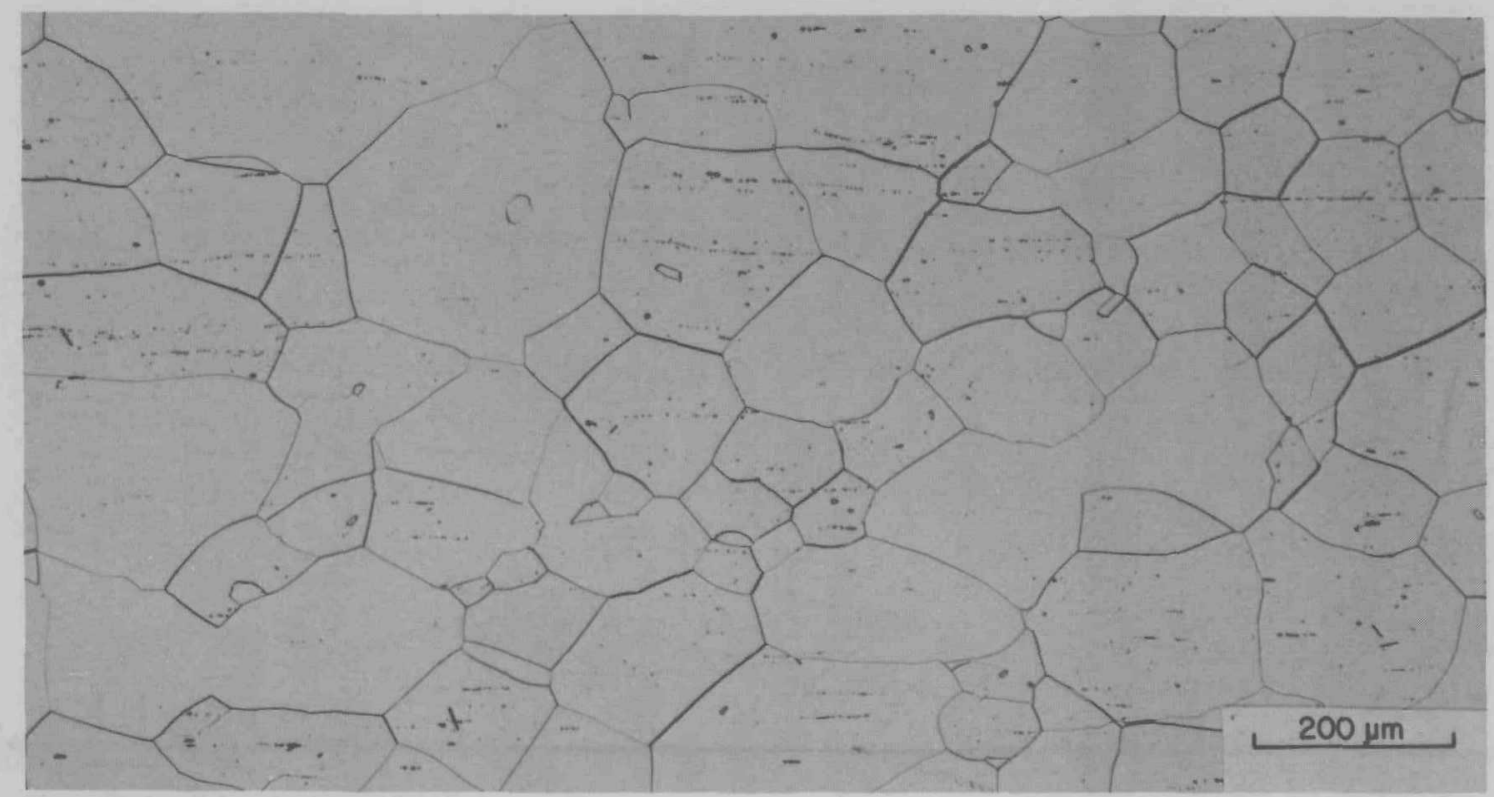

Fig. 25. Longitudinal structure of new-processed sheet recrystallized for $19 \mathrm{~h}$ at $1500^{\circ} \mathrm{C}$. 
CHEMICAL ANALYSES

Table 1 lists the results of chemical analyses for two ingots and the eight sheets that were fabricated. The top of each ingot was first trimmed and then sampled to determine if dopants of aluminum and thorium and also impurities had concentrated in the upper portion of the melt. Sampling of the sheets corresponded to the standard sheet qualifying procedure for certification of blanks. However, it can be seen from the data in Table 1 that there are no concentration gradients between the two ingots or among the eight sheets.

Al1 reported values in Table 1 meet specifications for flight-quality blanks of 2000 to $4000 \mathrm{ppm} \mathrm{W,} 30$ to $90 \mathrm{ppm} \mathrm{Th,} 20$ to $80 \mathrm{ppm} \mathrm{Al}$, and in general $50 \mathrm{ppm}$ maximum for each impurity, except $\mathrm{Fe}$ (150 ppm), Cr (25 ppm), C (35 ppm), and $\mathrm{Rh}(150 \mathrm{ppm})$. In comparison with standard-process material, the chemical results show improvement in uniformity of dopants of aluminum and thorium and also lower elemental contaminant contents. The remarkable low level of contaminants represents cast material of $14 \mathrm{~kg}$. This quantity corresponds to 28 standard-process ingots, each of which would have individual composition and corresponding variations in properties.

\section{NONDESTRUCTIVE EXAMINATIONS}

The 41 blanks that were cut from the eight sheets were examined to detect greater than 0.9 -mm-diam flaws with our standard-process ultrasonic inspection procedure; no indication of defects were found. In another test, the sensitivity of the ultrasonic examination was increased to reveal indications of flaws as small as $0.5 \mathrm{~mm}$ in diameter (ref. 6). Each blank was then retested; one blank from each extrusion was found to show reduced transmission of ultrasound in one area.

Our standard-process, dye-penetrant inspection revealed indications of pit-type defects on six blanks cut from the B-1 sheets; however, upon reworking and reinspection, all passed. No dye-penetrant indications of defects were found on blanks cut from the B-2 sheets.

Visual examination of standard process material revealed no defects on the 41 blanks from the $\mathrm{B}-1$ and $\mathrm{B}-2$ sheets. 
Table 1. Results of chemical analyses ${ }^{\alpha}$ on new-processed materials of iridium DOP-26 alloy

\begin{tabular}{|c|c|c|c|c|c|c|c|c|c|c|}
\hline \multirow{2}{*}{ Element } & \multicolumn{2}{|c|}{$\begin{array}{c}\text { Ingot analyses } \\
(\mathrm{ppm})\end{array}$} & \multicolumn{8}{|c|}{ Sheet analyses (ppm) } \\
\hline & B -1 & B-2 & B 1-1 & B 1-2 & B 1-4 & B $1-7$ & B2-1 & $\mathrm{B} 2-2$ & $B 2-5$ & $\mathrm{~B} 2-8$ \\
\hline $\mathrm{Ag}$ & 1 & 1 & 1 & 1 & 1 & 1 & 3 & 1 & 1 & 1 \\
\hline $\mathrm{A} 1$ & 42 & 43 & 58 & 50 & 68 & 50 & 60 & 37 & 44 & 42 \\
\hline $\mathrm{Au}$ & 5 & 3 & 3 & 3 & 3 & 3 & 3 & 1 & 3 & 5 \\
\hline $\mathrm{C}^{b}$ & 0.1 & 0.1 & 0.1 & 0.1 & $\begin{array}{ll} & 0.1 \\
30 & \& 24\end{array}$ & 0.1 & 0.1 & 0.1 & $\begin{aligned} & 0.1 \\
16 & \& 29\end{aligned}$ & 0.1 \\
\hline $\mathrm{Ca}$ & 0.5 & 0.1 & 0.1 & 0.3 & 0.1 & 0.1 & 1 & 0.1 & 0.1 & 0.5 \\
\hline $\mathrm{Cr}$ & 5 & 1 & 1 & 3 & 10 & 3 & 1 & 1 & 0.3 & 5 \\
\hline $\mathrm{Cu}$ & 3 & 1 & 10 & 10 & 5 & 3 & 3 & 3 & 1 & 3 \\
\hline $\mathrm{Fe}$ & 10 & 1 & 10 & 10 & 30 & 10 & 3 & 3 & 1 & 10 \\
\hline Mo & 10 & 5 & 3 & 5 & 3 & 3 & 1 & 1 & 1 & 1 \\
\hline $\mathrm{Na}$ & 0.3 & 0.3 & 0.3 & 0.3 & 0.1 & 0.1 & 3 & 0.3 & 0.1 & 0.3 \\
\hline $\mathrm{N}_{\frac{1}{b}}$ & 3 & 0.3 & 3 & 10 & $\begin{array}{r}30 \\
1 \& 1\end{array}$ & 10 & 1 & 1 & $3 \begin{array}{l}0.3 \\
3 \& 1\end{array}$ & 0.3 \\
\hline$P$ & 0.1 & 0.1 & 0.1 & 0.1 & 0.1 & 0.1 & 0.1 & 0.1 & 0.1 & 0.1 \\
\hline $\mathrm{Pd}$ & 1 & 3 & 1 & 3 & 3 & 3 & 3 & 3 & 3 & 3 \\
\hline $\mathrm{Pt}$ & 10 & 5 & 3 & 3 & 3 & 1 & 1 & 3 & 3 & 3 \\
\hline $\mathrm{Rh}$ & 1 & 5 & 1 & 1 & 1 & 1 & 0.3 & 1 & 1 & 1 \\
\hline $\mathrm{Ru}$ & 5 & 5 & 1 & 5 & 5 & 5 & 5 & 5 & 3 & 1 \\
\hline $\mathrm{S}$ & 3 & 1 & 3 & 3 & 3 & 1 & 3 & 3 & 3 & 1 \\
\hline Si & 5 & 1 & 1 & 1 & 10 & 3 & 3 & 5 & 3 & 3 \\
\hline $\mathrm{Ta}$ & 20 & 0.3 & 5 & 10 & 5 & 10 & 5 & 3 & 10 & 5 \\
\hline $\mathrm{Th}^{\mathrm{c}}$ & 53.7 & 66.3 & 62.1 & 52.9 & 49.2 & 60.0 & 61.0 & 65.8 & 62.6 & 71.5 \\
\hline $\mathrm{T} 1$ & 1 & 0.3 & 0.1 & 0.5 & 1 & 0.3 & 0.3 & 0.3 & 0.3 & 0.3 \\
\hline W & 3200 & 2600 & 3200 & 3000 & 2500 & 2500 & 2700 & 2500 & 2700 & 2600 \\
\hline $\mathrm{Zr}$ & 1 & 1 & 0.3 & 0.3 & 0.3 & 0.3 & 0.3 & 0.3 & 0.3 & 0.3 \\
\hline
\end{tabular}

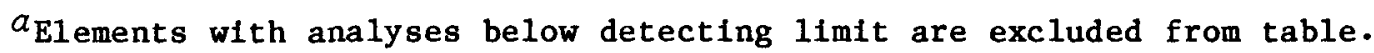

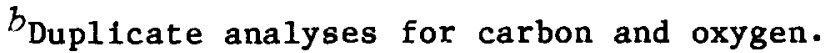

cIsotopic dilution mass spectrographic analysis. 
The results from our standard-process nondestructive examination for flight-quality hardware show that all the new-process blanks passed the tests for ultrasonic, dye-penetrant, and visual indications of flaws giving $0 \%$ defects. In comparison to standard-process blanks where rejections average 30 to $40 \%$, the new process appears to offer a significant increase in the yield of acceptable blanks. Additionally, the results for two sensitivities of simulated flaws (a blank with drilled flat-bottomed 0.9 - and $0.5-\mathrm{mm}$-diam holes) also suggest that reduction in permissible size of defect would increase rejection of otherwise flight-quality blanks by only $5 \%$.

\section{SUMMARY AND CONCLUSIONS}

Incorporation of iridium processing improvements into the standardprocess procedure showed positive results. The primary goal of reducing ultrasonic-detected defects from 30 to $15 \%$ or below was met with $100 \%$ acceptance of all blanks by the specified inspections for flight-quality hardware. The blanks were also inspected using a higher sensitivity inspecting process that increased the rejection rate in 41 tested blanks by only $5 \%$.

Homogeneity of the consumable arc, casting and extruding process was demonstrated, as no significant differences could be found in the microstructure between sheets produced from within a single extruded ingot or between two extruded ingots. The chemical analyses of the cast consumable electrode and the sheets rolled from the extrusions indicate that no elemental gradients occur on casting a 7-kg ingot, that dopant concentrations are uniform, and that trace elements are low and we 11 within specification.

It is apparent that the elimination of porosity and shrinkage defects from small arc-cast ingots contributed strongly to the reduction of defects in the rolled sheets. Also, the extrusion of large consumable arc-melted castings and their subsequent fabrication into sheet with increased hot reduction followed by a lower recrystallizing temperature treatment has potential to minimize the ingot-to-ingot variations in chemistry and structure that occur with the current standard process. 
The elimination of many steps in handling and recycling smal1 castings and apparent reductions in recycled iridium, chemical analyses, and defective blanks will undoubtedly reduce costs for future production. The first major step in acceptance of the new process for the fabrication of flight hardware now awaits the outcome of demonstrations to be conducted at MP on cup forming, at SRL on weldability, and at LANL on highstrain-rate biaxial mechanical properties for impact safety verification tests. The results of the above tests are scheduled for completion in 1986.

\section{ACKNOWLEDGMENTS}

The authors wish to thank the staff of the Metals Processing Laboratory for the fabrication development phase; G. C. Marsh for preparation and metallography of the specimens; D. N. Braski and T. K. Roche for technical review and comments; M. L. Anderson for preparing the draft manuscript; and S. A. Rupert, A. R. McDonald, and H. G. Sharpe for preparing the final report. In addition, the authors gratefully acknowledge the encouragement of Dr. W. J. Barnett, DOE/GTN.

\section{REFERENCES}

1. G. L. Bennett, J. J. Lombardo, and B. J. Rock, "Development and Use of Nuclear Power Sources for Space Applications," J. Astronautical Sci. 29(4), 321-43 (Oct.-Dec. 1981).

2. D. N. Braski and A. C. Schaffhauser, Production of Ir-0.3\% W Disks and Foiz, ORNL/TM-4865 (Apri1 1975).

3. D. N. Braski, M. D. Allen, and A. C. Schaffhauser, "Metallography in Iridium Sheet Production," pp. 745-60 in Microstructural Science 3, ed. P. M. French, R. J. Gray, and J. L. McCall, American Elsevier Publishing Company, New York, 1975.

4. C. T. Liu and H. Inouye, Development and Characterization of an Improved Ir-0.3\% W Alloy for Space Radioisotopic Heat Sources, ORNL-5290 (October 1977). 
5. C. T. Liu, H. Inouye, and A. C. Schaffhauser, "Effect of Thorium Additions On Metallurgical and Mechanical Properties of Ir-0.3 Pct. W A1loys," Metal. Trans. A 12A, 993-1001 (June 1981).

6. K. V. Cook, R. A. Cunningham, W. H. Simpson, Jr., R. W. McClung, ULtrasonic Detection of Lamination-Type Defects in Iridium AlZoy Blanks, ORNL report in preparation. 
ORNL -6270

Dist. Category UC-25

INTERNAL DISTRIBUTION

1-2. Central Research Library

3. Document Reference Section

4-5. Laboratory Records Department

6. Laboratory Records, ORNL RC

7. ORNL Patent Section

8. D. E. Bartine

9. R. A. Bradley

10. J. C. Brown

11. K. V. Cook

12-13. R. H. Cooper, Jr.

14-18. G. L. Copeland

19. C. E. Dunn

20. J. I. Federer

21. G. M. Goodwin

22-26. R. L. Heestand

27. D. 0. Hobson
28. R. R. Judkins

29. B. C. Leslie

30-34. M. M. Martin

35. R. W. McClung

36. W. H. Miller

37. A. C. Schaff hauser

38. V. K. Sikka

39. G. M. Slaughter

40-42. P. T. Thornton

43. F. W. Wiffen

44. R. J. Charles (Consultant)

45. G. Y. Chin (Consultant)

46. H. E. Cook (Consultant)

47. Alan Lawley (Consultant)

48. W. D. Nix (Consultant

49. J. C. Williams (Consultant)

EXTERNAL DISTRIBUTION

50. Battelle Columbus Laboratories, 505 King Avenue, Columbus, $\mathrm{OH} 43201$

C. A. Alexander

51-52. E. I. du Pont de Nemours \& Company, Savannah River Plant, Aiken, SC 29801

J. K. Brown

W. R. Kanne

53-54. Fairchild Industries, 20301 Century Boulevard, Germantown, MD 20767

M. B. Eck

A. Schock

55-58. General Electric Company, Spacecraft Operations, P.0. Box 8555, Room 29B12, Philadelphia, PA 19101
H. M. Da1a1
R. J. Hemler
P. Gorsuch
J. R. Peterson

59-60. Jet Propulsion Laboratory, California Institute of Technology, 4800 Oak Grove Drive, Pasadena, CA 91103

R. W. Campbe11

A. E. Wolfe 
61. Johns Hopkins University, Applied Physics Laboratory, Johns Hopkins Road, Laure1, MD 20810

J. C. Hagan

62-64. Los Alamos National Laboratory, P.0. Box 1663, Los Alamos, NM 87545

S. E. Bronisz

T. George

T. C. Wallace, Sr.

65-67. Monsanto Research Corporation, Mound Plant, P.0. Box 32, Miamisburg, $\mathrm{OH} 45342$

W. R. Amos

H. F. Anderson

R. Saylor

68. Teledyne Energy Systems, 110 W. Timonium Road, Timonium, MD 21093

P. Dick

69. Air Force Weapons Laboratory/AWYS, Kirtland Air Force Base, NM 87117

J. K. Hipp

70-77. Department of Energy, Division of Special Applications, Office of Defense Energy Projects and Special Applications, Office of Nuclear Energy, NE-522, MS B-435, 19901 Germantown Road, Germantown, MD 20874
W. J. Barnett
J. J. Lombardo
G. L. Bennett
R. B. Morrow
R. C. Brouns
A. L. Mowery
J. S. Griffo
K. G. Sommer

78-79. Department of Energy, Albuquerque Operations Office, P.0. Box 5400, Albuquerque, NM 87115
R. Holton
R. Y. Lowrey

80. Department of Energy, Dayton Area Office, P.0. Box 66, Miamisburg, OH 45342

J. A. Morley

81. Department of Energy, Oak Ridge Operations Office, P.0. Box E, Oak Ridge, TN 37831

Office of Assistant Manager for Energy Research and Development 
82. Department of Energy, Savannah River Operations of $f$ ice, P.0. Box A, Aiken, SC 29801

G. M. Nichols, Jr.

83-259. Department of Energy, Technical Information Center, P.0. Box 62, Oak Ridge, TN 37831

For distribution as shown in DOE/TIC-4500, Distribution Category UC-25 (Materials). 